Anuario da Facultade de Dereito da Universidade da Coruña

Vol. 23 (2019), pp. 373-410

ISSNe: 2530-6324 || ISSN: 1138-039X

DOI: https://doi.org/10.17979/afdudc.2019.23.0.6028

\title{
LA COAUTORÍA CON IMPRUDENCIA DESDE LA TEORÍA DE LA DETERMINACIÓN OBJETIVA Y POSITIVA DEL HECHO. UNA REINTERPRETACIÓN DEL PAPEL DEL ACUERDO PARA REFORZAR EL CARÁCTER OBJETIVO DE LA TEORÍA ${ }^{1}$
}

\section{CO-PERPETRATORSHIP WITH NEGLIGENCE APPLYING THE THEORY OF OBJECTIVE AND POSITIVE DETERMINATION OF THE FACT. A PROPOSAL FOR A DIFFERENT UNDERSTANDING OF THE AGREEMENT IN ORDER TO REINFORCE THAT THEORY}

\author{
VIRGILIO RODRÍGUEZ VÁZQUEZ ${ }^{2}$ \\ Profesor Contratado Doctor (acred. Profesor Titular) de Derecho Penal \\ Universidad de Vigo
}

\begin{abstract}
Resumen: Desde la teoría de la determinación objetiva y positiva del hecho se ha propuesto un concepto de coautoría aplicable tanto al delito doloso como imprudente, que se diferencia de los defendidos desde otros sectores doctrinales no tanto por los requisitos que se exigen para constatar la coautoría (objetivo y subjetivo), sino por el contenido que dichos elementos deben poseer. En este trabajo expongo los conceptos de coautoría y de autoría accesoria desde la perspectiva de la teoría de la determinación objetiva y positiva del hecho para cuestionar el papel que se le otorga al "acuerdo" en esta postura, haciendo un análisis crítico. Finalmente, realizo una propuesta para un entendimiento distinto del elemento subjetivo "acuerdo" que, a mi modo de ver, resulta más coherente con las bases conceptuales de esta teoría y que, por tanto, la refuerza.
\end{abstract}

\footnotetext{
${ }^{1}$ El presente trabajo se inscribe en el proyecto de investigación "Responsabilidad penal de personas físicas y jurídicas en el ámbito empresarial, económico, laboral y de los mercados (II)" (Referencia: DER2014-58546-R, Ministerio de Economía y Competitividad), del que es investigador principal el Prof. Dr. Dr. h. c. mult. Diego-Manuel Luzón Peña, Catedrático de Derecho Penal de la Universidad de Alcalá de Henares, así como también en el proyecto de investigación "Principios y garantías penales: sectores de riesgo" (Referencia: DER2016-76715-R, Ministerio de Ciencia e Innovación) del que es investigador principal el Prof. Dr. Dres. h. c. Miguel Díaz y García Conlledo, Catedrático de Derecho Penal de la Universidad de León, y de cuyos equipos de trabajo formo parte.

${ }^{2}$ Facultad de Derecho de la Universidad de Vigo. Campus de Ourense, s/n, 32004 Ourense, España. virxilio@uvigo.es.
} 
Palabras clave: autoría y participación, coautoría, autoría accesoria, concepto restrictivo de autor, teoría de la determinación objetiva y positiva del hecho.

Abstract: Based on the theory of the objective and positive determination of the act, a concept of co- perpetratorship has been proposed. This concept is applicable to intentional crimes and reckless crimes, and it differs from other concepts defended from other doctrinal sectors. The difference stands not so much on the requirements that are requested to affirm the co- perpetratorship (objective and subjective), but for the content that these elements must possess. In this work the author exposes the concepts of coperpetratorship and accessorial-perpetratorship from the perspective of the theory of the objective and positive determination of the act, making a critical analysis to question the role that is granted to the "agreement". Finally, the author makes a proposal for a different understanding of the subjective element "agreement", that is more coherent with the conceptual bases of this theory and, therefore, reinforces it.

Keywords: perpetratorship and participation, co-perpetratorship, accessorialperpetratorship, restrictive concept of perpetrator, objective and positive determination of the act.

Sumario: I. INTRODUCCIÓN. II. LA COAUTORÍA DESDE LA TEORÍA DE LA DETERMINACIÓN OBJETIVA Y POSITIVA DEL HECHO. 1. El requisito objetivo: la co-determinación del hecho. 2 . El requisito subjetivo: el acuerdo. III. AUTORÍA ACCESORIA VS. COAUTORÍA Y EL CRITERIO UTILIZADO PARA ATRIBUIR EL HECHO A LOS VARIOS INTERVINIENTES. IV. CRÍTICA, DESDE LA TEORÍA DE LA DETERMINACIÓN OBJETIVA Y POSITIVA DEL HECHO, A LA UTILIZACIÓN DEL ACUERDO COMO REQUISITO NECESARIO PARA LA IMPUTACIÓN RECÍPROCA EN LA COAUTORÍA. V. UNA PROPUESTA DE REINTERPRETACIÓN DEL PAPEL DEL ACUERDO Y DE SU UBICACIÓN SISTEMÁTICA EN LA COAUTORÍA CON IMPRUDENCIA. VI. CONTENIDO DEL ACUERDO EN LA COAUTORÍA CON IMPRUDENCIA CONJUNTA. VII. CONCLUSIONES. VIII. BIBLIOGRAFÍA.

\section{INTRODUCCIÓN}

El CP español no se inclina de forma clara e inequívoca por un determinado concepto de autor ${ }^{3}$. Es necesario decidir cuál de los diferentes conceptos de autor

\footnotetext{
${ }^{3}$ Las diversas posibles interpretaciones de las disposiciones legales que se refieren a la autoría y a la participación en la Parte general del CP, y la falta de un pronunciamiento claro, permiten pensar que se trata de una cuestión que el legislador ha decidido dejar abierta a la interpretación. Cfr. DÍAZ Y GARCÍA CONLledO, M., La autoría en Derecho Penal, Madrid, 1991, pág. 251, aunque se refiere al CP $1944 / 73$, sus razonamientos y conclusiones son perfectamente aplicables al CP vigente; ROSO CAÑADILLAS, R., Autoría y participación imprudente, Granada, 2002, págs. 305 y s.; PÉREZ ALONSO, E.J., La coautoría y la complicidad (necesaria) en Derecho penal, Peligros (Granada), 1998, pág. 142. En sentido contrario, LÓPEZ BARJA DE QUIROGA, J., Autoría y participación, Madrid, 1996, pág. 38, señala: "Como hemos dicho, el CP debe utilizar términos que permitan la aplicación de diversas teorías, pues, la autoría es un fenómeno que tiene que ser atrapado legislativamente con la
} 
desarrollados por la doctrina es preferible adoptar y por qué. En España, la mayoría de la doctrina opta por el concepto restrictivo de autor ${ }^{5}$, por entender que es el que mejor se adapta a los principios inspiradores de un Derecho penal propio de un Estado de Derecho. Concretamente, se considera que el concepto restrictivo se ajusta mejor que cualquier otro al principio de legalidad, en su vertiente de determinación y taxatividad, $\mathrm{y}$, en consecuencia, al principio de seguridad jurídica, así como también a los principios de ultima ratio e intervención mínima ${ }^{6}$. Otras razones que se aducen para justificar la

suficiente amplitud. El legislador debe marcar únicamente ciertas pautas que deben considerarse un sistema de mínimos y, más tarde, el intérprete en función de una u otra teoría llegará a las soluciones que le parecerán más acertadas. Esto debería ocurrir con el CP de 1995, pero, al menos en materia de autoría y participación, ha de afirmarse que no se ha logrado siempre con el acierto preciso. El Código claramente excluye un concepto unitario de autor, desde el momento en que separa las conductas de los autores y de los que también son considerados autores; y, por otro lado, además, separa de forma patente a los cómplices"; SÁINZ-CANTERO CAPARRÓS, J.E., La “codelincuencia” en los delitos imprudentes en el Código penal de 1995, Madrid, 2001, págs. 16, 97 y s., indica: "Hay que señalar como opinión doctrinal unánime la afirmación de que el CP español de 1995 acoge un concepto restringido de autor”. También, véase, MIR PUIG, S., Derecho Penal, PG, 10ª ed., Barcelona, 2016, pág. 379.

${ }^{4}$ Sobre los diferentes conceptos de autor, unitario, extensivo y restrictivo, sus defensores y evolución histórica, cfr., entre otros, GIMBERNAT ORDEIG, E., Autor y cómplice en Derecho penal, Madrid, 1966, págs. 43 y ss.; PEÑARANDA RAMOS, E., La participación en el delito y el principio de accesoriedad, Madrid, 1990, págs. 257 y ss.; DÍAZ Y GARCÍA CONLLEDO, M., La autoría, cit., págs. 43 y ss.; el mismo, "La autoría en Derecho penal. Caracterización general y especial atención al Código Penal colombiano", DPCrim 2004, págs. 35 y s.; ROXIN, C., Autoría y dominio del hecho en Derecho penal, 7.a., Madrid, 2000, págs. 71 y ss.; SÁNCHEZ LÁZARO, F.G., Intervención delictiva e imprudencia, Granada, 2004, págs. 27 y ss.; GÓMEZ MARTÍN, V., Los delitos especiales, Madrid/Montevideo, 2006, págs. 257 y ss.; MIR PUIG, S., PG, cit., págs. 379 y ss.

${ }^{5}$ Cfr. DÍAZ Y GARCÍA CONLLEDO, M., La autoría, cit., págs. 132, 201; el mismo, "Autoría y participación”, LL 1996-2, pág. 1284; GONZÁLEZ RUS, J.J., “Autoría única inmediata, autoría mediata y coautoría”, CDJ 1994-XXXIX, pág. 101; GÓMEZ RIVERO, M.C., La inducción a cometer el delito, Valencia, 1995, págs. 25 y ss.; PAREDES CASTAÑÓN, J.M., en PAREDES CASTAÑÓN, J. M./RODRÍGUEZ MONTAÑÉS, T., El caso de la colza: responsabilidad penal por productos adulterados o defectuosos, Valencia, 1995, pág. 148; PÉREZ ALONSO, E.J., La coautoría, cit., pág. 134; PÉREZ MANZANO, M., Autoría y participación imprudente en el Código Penal de 1995, Madrid, 1999, pág. 78; LUZÓN PEÑA, D.-M./DÍAZ Y GARCÍA CONLLEDO, M., "Determinación objetiva y positiva del hecho y realización típica como criterios de autoría", AFDUA 8 (1998-1999), pág. 80; los mismos, "Objektive positive Tatbestimmung und Tatbestandsverwirklichung als Täterschaftsmerkmale", FSRoxin, 2001, pág. 601; los mismos, "Determinación objetiva y positiva del hecho y realización típica como criterios de autoría", RDCP 2003-2, pág. 119; ROSO CAÑADILLAS, R., Autoría, cit., pág. 306; DURÁN SECO, I., La coautoría en Derecho Penal, aspectos esenciales, León, 2003, págs. 54 y s.; SÁNCHEZ LÁZARO, F.G., Intervención, cit., pág. 27; GARCÍA MOSQUERA, M., La estafa de seguro, Madrid, 2006, pág. 256; RODRÍGUEZ VÁZQUEZ, V., Responsabilidad penal en el ejercicio de actividades médico-sanitarias. Criterios para delimitar la responsabilidad penal en supuestos de intervención conjunta de los profesionales sanitarios, Madrid, 2012, págs. 373 ss.; ESCOBAR VÉLEZ, S., La responsabilidad penal por productos defectuosos, Valencia, 2012, pág. 99; RODRÍGUEZ MESA, M.J., "Los delitos de omisión impropia como delitos especiales y de dominio positivo del hecho. Repercusiones en materia de autoría y participación", REDUR 11/2013, págs. 110 y ss.; ALPACA PÉREZ, A., Delitos tributarios y aduaneros, Lima, 2015, págs. 578 y s.; MIR PUIG, S., PG, cit., págs. 379 y ss.; FRANCÉS LECUMBERRI, P., El desvalor penal de la contabilidad creativa y otras problemáticas a la luz del bien jurídico protegido en el art. 290 CP, Valencia, 2017, págs. 253 y s.; PÉREZ-SAUQUILLO MUÑOZ, C., "Reflexiones y críticas sobre el pensamiento de la acumulación", LLP 2017-128, págs. 27 y s., n. 61; TORRES CADAVID, N., "La responsabilidad penal del asesor fiscal en el delito de defraudación tributaria del art. 305 CP español. La aplicación de la cláusula del actuar en lugar de otro", NFP 90 (2018), págs. 83 y s.; la misma, La responsabilidad penal del asesor fiscal. Problemas de autoría y participación en el delito de defraudación tributaria, Valencia, 2019, págs. 403 y s.

${ }^{6}$ DÍAZ Y GARCÍA CONLLEDO, M., La autoría, cit., págs. 201 y s.; en el mismo sentido, LUZÓN PEÑA, D.-M./DÍAZ Y GARCÍA CONLLEDO, M., "Determinación”, cit., pág. 57; los mismos, “Objektive positive Tatbestimmung”, cit., pág. 578; los mismos, "Determinación objetiva”, cit., pág. 94; 
adopción del concepto restrictivo de autor son: a) la imperfección del legislador, a la que se refiere DÍAZ Y GARCÍA CONLLEDO ${ }^{7}$; b) que la interpretación restrictiva es acorde con la postura tradicionalmente asumida por la doctrina en España, de manera que si no hay razones para el cambio, ésta es la opción que se debe adoptar ${ }^{8}$; c) que, acudiendo a un criterio prejurídico (aunque siempre con un valor limitado, sobre todo en esta materia), se puede decir que "el concepto restrictivo de autor se aproxima más a la realidad de los fenómenos sociales participativos, a los conceptos vulgares de autor y partícipe, etc." 9 .

De entre las distintas teorías desarrolladas dentro del concepto restrictivo, entre las cuales destacan la teoría objetivo-formal, la teoría objetivo-material, la teoría del dominio del hecho, entre otras ${ }^{10}$, en mi opinión, la que mejor respeta y garantiza los principios señalados es la "teoría de la determinación objetiva y positiva del hecho", siendo además aplicable tanto a los delitos dolosos como a los imprudentes ${ }^{11}$. Esta

ROSO CAÑADILLAS, R., Autoría, cit., pág. 307; DURÁN SECO, I., La coautoría, cit., págs. 55 y s.; SÁNCHEZ LÁZARO, F.G., Intervención, cit., pág. 34; MIR PUIG, S., PG, cit., págs. 379 y ss.

${ }^{7}$ DÍAZ Y GARCÍA CONLLEDO, M., La autoría, cit., págs. 201 y s.; en el mismo sentido, LUZÓN PEÑA, D.-M./DÍAZ Y GARCÍA CONLLEDO, M., "Determinación”, cit., pág. 57; los mismos, “Objektive positive Tatbestimmung”, cit., pág. 578; los mismos, "Determinación objetiva”, cit., pág. 94.

${ }^{8}$ DÍAZ Y GARCÍA CONLLEDO, M., La autoría, cit., pág. 202; DURÁN SECO, I., La coautoría, cit., pág. 56; en términos similares, SÁINZ-CANTERO CAPARRÓS, J.E., La codelincuencia, cit., págs. 97 y s.

${ }^{9}$ DURÁN SECO, I., La coautoría, cit., págs. 56 y s.

${ }^{10}$ El concepto restrictivo de autor puede tener una amplitud mayor o menor dependiendo del criterio que se adopte para definir la autoría y diferenciarla de la participación en sentido estricto. Las principales teorías que se han desarrollado son la objetivo-formal, la objetivo-material, la teoría del dominio del hecho, entre otras. Sobre estas teorías, y con ulteriores referencias, cfr., GIMBERNAT ORDEIG, E., Autor, cit., págs. 10 y ss., 19 y ss., 215 y ss.; DÍAZ Y GARCÍA CONLLEDO, M., La autoría, cit., págs. 411 y ss.; el mismo, "Autoría”, EPB, 2002, pág. 144; COBO DEL ROSAL, M./VIVES ANTÓN, T. S., Derecho Penal, $P G, 5^{\text {a }}$ ed., Valencia, 1999, págs. 670 y s.; ROXIN, C., Autoría, cit. págs. 54 y ss., 697; MIR PUIG, S., $P G$, cit., págs. 382 y ss.

${ }^{11}$ Sobre una valoración positiva de esta teoría, véase, entre otros, GÓMEZ RIVERO, M.C., La inducción, cit., págs. 340 y ss., 343, que señala "que la concepción de LUZÓN es loable por suponer, frente al concepto unitario de autor, una precisa delimitación del título de responsabilidad de cada uno de los intervinientes en el delito doloso"; en el mismo sentido, PÉREZ ALONSO, E.J., La coautoría, cit., págs. 59 y ss.; VILLACAMPA ESTIARTE, C., Responsabilidad penal del personal sanitario. Atribución de responsabilidad penal en tratamientos médicos efectuados por diversos profesionales sanitarios, Cizur Menor, 2003, págs. 233 y s., afirma que "quizá el intento más relevante de adopción de un concepto unívoco de autor válido igualmente para el delito doloso e imprudente ha sido el protagonizado por LUZÓN PEÑA. (...) La concepción de LUZÓN PEÑA, por su indiscutible contribución al deslinde de la objetividad respecto de la subjetividad en el dominio del hecho, y por su operatividad en punto a la superación de una concepción apegada a la equivalencia de las condiciones en la intervención imprudente, ha sido seguida y desarrollada por un sector de la doctrina en nuestro país"; SÁNCHEZ LÁZARO, F.G., Intervención, cit., págs. 65, 68, quien advierte que "estas ideas iniciales de LUZÓN PEÑA fueron desarrolladas posteriormente por su discípulo DÍAZ Y GARCÍA CONLLEDO en una importante monografía, y han dado lugar a una de las teorías más implantadas dentro de nuestra doctrina"; "el grado de desarrollo alcanzado por la teoría de la autoría y participación en nuestro país tiene mucho que ver con el trabajo realizado por LUZÓN PEÑA y sus discípulos; y la teoría que proponen, dentro de las de carácter fenomenológico, constituye, a nuestro juicio, la más sugerente de las realizadas hasta ahora para los delitos imprudentes"; DEL CASTILLO CODES, E., La imprudencia, cit., pág. 75, precisa que "la autoría, también en los delitos imprudentes, tiene que ser definida a partir de un efectivo dominio, y en este sentido destaca, en nuestra doctrina, la tesis de LUZÓN PEÑA"; CADAVID QUINTERO, A., Imprudencia punible y actividad médico-quirúrgica, tesis d., Salamanca, 2013, pág. 337, reconoce que "Teorías como la de la determinación objetiva y positiva del hecho, están animadas por una loable pretensión de restringir el espacio de los autores al de los ejecutores de las conductas medulares para la infracción delictiva, contraviniendo con ello las pretensiones expansivas del Derecho 
teoría es creada por LUZÓN PEÑA ${ }^{12}$, desarrollada posteriormente por su discípulo DÍAZ Y GARCÍA CONLLEDO ${ }^{13 / 14}$, y seguida por una amplia Escuela ${ }^{15}$, además de otros autores ${ }^{16}$.

penal del último tiempo que pretende imputar responsabilidad como autor a cualquiera que haya efectuado alguna aportación al hecho, o se haya abstenido de neutralizar el riesgo en proceso de desarrollo".

Sobre las críticas, cfr. entre otros, GÓMEZ RIVERO, M.C., La inducción, cit., págs. 342 y ss.; HERNÁNDEZ PLASENCIA, J.U., La autoría mediata en Derecho penal, Granada, 1996, pág. 136; VILLACAMPA ESTIARTE, C., Responsabilidad, cit., págs. 234 y ss.; SÁNCHEZ LÁZARO, F.G., Intervención, cit., págs. 64 y ss.; DEL CASTILLO CODES, E., La imprudencia: autoría y participación, Madrid, 2007, págs. 81 y ss.; MIR PUIG, S., $P G$, cit., págs. 34 y s., n. 32. Una exposición pormenorizada de las críticas a las que se ha visto sometida la teoría de la determinación objetiva y positiva, así como una contestación detallada a las mismas se puede ver en DURÁN SECO, I., La coautoría, cit., págs. 286 y ss.; ESCOBAR VÉLEZ, S., La responsabilidad, cit., págs. 101 y ss.; RODRÍGUEZ VÁZQUEZ, V., Responsabilidad, cit., págs. 342 y ss.; TORRES CADAVID, N., La responsabilidad, cit., págs. 383 y ss.

${ }^{12}$ Esta teoría es propuesta por primera vez en LUZÓN PEÑA, D.-M., "Autoría e imputación objetiva en el delito imprudente: valoración de las aportaciones causales (Comentario a la STS de 27 de enero de 1984)", RDCir 1984, págs. 275 y ss., pero el estudio fundamental es LUZÓN PEÑA, D.-M., “Alcance y función del Derecho penal", ADPCP 1989, págs. 889 y ss. (publicado también en Derecho Penal de la Circulación. Estudios de la jurisprudencia del Tribunal Supremo, 2a ed., Barcelona, 1990, págs. 105 y ss.; y en Estudios Penales, Barcelona, 1991, págs. 197 y ss.).

${ }^{13}$ Cfr. DÍAZ Y GARCÍA CONLLEDO, M., La autoría, cit., págs. 625, 688 y ss. Sobre la génesis de esta teoría, DÍAZ Y GARCÍA CONLLEDO, M., "La autoría en Derecho penal”, cit., pág. 44. Cfr. también los más recientes trabajos de DÍAZ Y GARCÍA CONLLEDO en materia de autoría y participación, "Der Einfluss der Roxinschen Täterschaftstheorie (insbesondere betreffend die Mittäterschaft) auf die spanische Rechtslehre und Rechtsprechung: Kritische Betrachtungen”, GA 2011, págs. 259-283; el mismo, "La influencia de la teoría de la autoría (en especial, de la coautoría) de Roxin en la doctrina y la jurisprudencia españolas: consideraciones críticas”, NFP 76 (2011), págs. 15-48; el mismo, “Algunas cuestiones en relación con el delito de administración desleal societaria en España, es especial autoría y omisión", NFP 83 (2014), págs. 15-38; el mismo, "Strafrechtliche Verantwortlichkeit juristischer Personen? Einige Thesen”, GA 2016, págs. 238-248; el mismo, “¿Responsabilidad penal de las personas jurídicas? Algunas tesis", Libertas 5 (2016), págs. 31-43; el mismo, Lectio Doctoralis: Claus Roxin y la llamada autoría mediata por utilización de aparatos organizados de poder, Lima/León, 2016, págs. 5 y ss.; el mismo, "Das Handeln im Rahmen eines organisatorischen Machtapparates: Täterschaft oder Teilnahme?”, GA 2017, págs. 711-719; el mismo, “Actuación en el marco de un aparato organizado de poder: ¿autoría o participación?”, LH-Mir, 2017, págs. 509-521; el mismo, “Claus Roxin y la llamada autoría mediata por utilización de aparatos organizados de poder (Lectio doctoralis)", RAP 32 (2017), págs. 373-388; el mismo, "Un diálogo crítico con Claus Roxin y su teoría de la autoría", CPC 2017, págs. 5-40; el mismo, "Claus Roxin y la teoría de la autoría. Algunas discrepancias", LH-Roxin (Lima), 2018, págs. 137-175; el mismo, "Algunos problemas que plantea la criminalidad organizada en la teoría general del delito, en especial en materia de autoría y participación”, en: VV.AA., Globalización y lucha contra las nuevas formas de criminalidad transnacional (Galán Muñoz, Alfonso, Mendoza Calderón, Silvia, dirs.), Tirant lo Blanch, Valencia, 2018, págs. 33-54.

${ }^{14}$ La primera exposición en conjunto y por escrito de su teoría está en LUZÓN PEÑA, D.-M./DÍAZ Y GARCÍA CONLLEDO, M., "Determinación objetiva”, cit., págs. 89 y ss., que se corresponde con la versión colombiana del artículo publicado en alemán en FS-Roxin, 2001 ("Objektive positive Tatbestimmung", cit.) págs. 575 y ss.

15 Entre los autores de esta Escuela destacan, DE VICENTE REMESAL, J./DÍAZ Y GARCÍA CONLLEDO, M., "Autoría o participación en determinados supuestos de 'vigilancia' (Comentarios a la STS de 21 de febrero de 2989) (Pte. BACIGALUPO ZAPATER)", PJ 27, pág. 209; PAREDES CASTAÑÓN, J. M., en PAREDES CASTAÑÓN, J. M./RODRÍGUEZ MONTAÑÉS, T., El caso, cit., pág. 149; OLAIZOLA NOGALES, I., El delito de cohecho, Valencia, 1999, pág. 174; RODRÍGUEZ MONTAÑÉS, T., "Imprudencia”, EPB, 2002, pág. 795; ROSO CAÑADILLAS, R., Autoría, cit., págs. 580 y ss.; DURÁN SECO, I., La coautoría, cit., págs. 45 y ss.; GARCÍA MOSQUERA, M., La estafa, cit., pág. 256; RODRÍGUEZ VÁZQUEZ, V., Responsabilidad, cit., págs. 371 y s.; ESCOBAR VÉLEZ, S., La responsabilidad, cit., pág. 99; VALLEJO JIMÉNEZ, Responsabilidad penal sanitaria, tesis d., 2012, 222; ALPACA PÉREZ, A., Delitos tributarios y aduaneros, cit., págs. 578 y s., n. 1193; FRANCÉS LECUMBERRI, P., El desvalor, cit., pág. 254; PÉREZ-SAUQUILLO MUÑOZ, C., 
Esta teoría exige que se cumplan dos requisitos para poder afirmar la autoría. Por una parte, es necesario que el sujeto en cuestión ocupe una posición especialmente relevante en relación con el hecho, que le permita decidir más allá de la "no producción del hecho" y, además, sobre su concreta forma de producción ${ }^{17}$. Así, el sujeto guarda una auténtica posición de control o dirección sobre el hecho delictivo ${ }^{18}$; en palabras de LUZÓN PEÑA "Ello supone que la conducta marca y fija forzosamente el curso del hecho a la producción del resultado típico, es decisiva, decide sobre el si y el cómo del curso del acontecimiento, y por ello determina objetiva y positivamente el hecho típico; esa cualidad o circunstancia, la determinación objetiva del hecho, es la misma base objetiva que, cuando hay dolo, permite hablar de 'dominio del hecho' y distinguir así en las contribuciones causales entre autoría o realización del hecho típico y participación o mero favorecimiento causal de la realización del hecho" "19. Por otra parte, debe hablarse de "dominio" en términos exclusivamente objetivos, atendiendo a la relevancia de la acción en relación con el hecho típico, cuyo análisis y valoración no depende de que el conocimiento o la voluntad del agente abarquen o no las circunstancias que convierten a esa acción en decisiva para la producción del hecho típico, sino de que la acción, valorada en sí misma y atendiendo a las circunstancias concretas del caso, sea suficiente para la producción del resultado, de ahí que se prefiera el término "determinación" 20.

"Reflexiones", cit., págs. 27 y s.; TORRES CADAVID, N., "La responsabilidad penal”, cit., págs. 83 y ss.; la misma, La responsabilidad, cit., pág. 400.

${ }^{16}$ Entre los autores que siguen esta teoría, además de los ya mencionados supra, de manera enunciativa: JORGE BARREIRO, Ag., La imprudencia punible en la actividad médico-quirúrgica, Madrid, 1990, pág. 124; JORGE BARRERO, Al., "La imprudencia profesional", CDJ 1993-I, pág. 247; CALDERÓN CEREZO, A., "Autoría y participación en el delito imprudente. Concurrencia de culpas", CDJ 1993-I, 28; GONZÁLEZ RUS, J. J., "Autoría”, cit., págs. 84 y ss.; GÓMEZ RIVERO, M.C., La inducción, cit., págs. 342 y ss., aunque con ciertos matices en lo que se refiere a las consecuencias de la teoría en relación con la participación imprudente, según la interpreta la autora; LÓPEZ PEREGRÍN, M.C., La complicidad en el delito, Valencia, 1997, págs. 392 y s.; GÓMEZ TOMILLO, M., Libertad de información y teoría de la codelincuencia. La autoría y la participación en los delitos cometidos a través de los medios de comunicación de masas, Granada, 1998, págs. 217 y s., 229, n. 276, 271, n. 396; GARCÍA ÁLVAREZ, P., La puesta en peligro de la vida y/o integridad fisica asumida voluntariamente por su titular, Valencia, 1999, págs. 158 y ss.; SÁINZ-CANTERO CAPARRÓS, J.E., La codelincuencia, cit., pág. 94; SOTO NIETO, F., "Coautoría en los delitos de imprudencia médica", $L L$ 2002-7, pág. 1775; BOLEA BARDÓN, C., La cooperación necesaria: análisis dogmático y jurisprudencial, Barcelona, 2004, págs. 47 y s.; ARAMBURO CALLE, M., "La delincuencia en la empresa: problemas de autoría y participación en delitos comunes", NFP 68 (2005), págs. 101 y s.; SUÁREZ SÁNCHEZ, A., Autoría, Bogotá, 2007, passim., pero especialmente págs. 24, 264, 390 y s.; RODRÍGUEZ MESA, M.J., "Los delitos", cit., págs. 110 y ss.; CADAVID QUINTERO, A., Imprudencia, cit., págs. 412 y s. Cfr. además DÍAZ Y GARCÍA CONLLEDO, M., "Un diálogo", cit., págs. 10 y s., n. 10, que relata los puntos de contacto entre la teoría de la determinación objetiva y positiva del hecho y la postura de otros autores en la doctrina española, y, además, expone los autores que han señalado la compatibilidad de esta teoría con la regulación de la autoría y la participación en el CP vigente.

${ }^{17}$ En este sentido, ya apuntaba LUZÓN PEÑA, D.-M., Derecho, cit., pág. 95, pensando inicialmente en los delitos imprudentes que: "El del dominio objetivo y positivo (no meramente negativo) del hecho, es decir, la posición de control del hecho (con independencia de su intención) por parte del sujeto, aislada o conjuntamente con otras personas, sobre la producción del resultado, pudiendo decidir positivamente el si y el cómo de la misma; a este respecto dominio (o control) objetivo positivo es más que el mero dominio negativo del hecho o posibilidad de impedirlo si quisiera". Así también, DÍAZ Y GARCÍA CONLLEDO, M., La autoría, cit., pág. 626 y s.

${ }^{18}$ LUZÓN PEÑA, D.-M., "Alcance”, cit., págs. 895 y s.; el mismo, Lecciones de Derecho Penal, PG, $3^{\text {a }}$ ed., Valencia, 2016, § 18/50; también por DÍAZ Y GARCÍA CONLLEDO, M., La autoría, cit., pág. 628. ${ }^{19}$ LUZÓN PEÑA, D.-M., Lecciones, cit., § 18/50.

${ }^{20}$ Así, LUZÓN PEÑA, D.-M., "Alcance”, cit., págs. 892 y s., 897; el mismo, Curso de Derecho Penal, Madrid, 1996, pág. 509: “(...) existe (...) un dominio objetivo o control objetivo del hecho, que 
En resumen, autor será aquel que a través de su acción "determine" el si y el cómo, e independientemente de los aspectos subjetivos que concurran, del hecho.

La teoría de la determinación objetiva y positiva del hecho respeta escrupulosamente los elementos configuradores de un concepto restrictivo de autor, proporcionando una base material para distinguir entre formas de autoría y participación. Además, entre sus virtudes dogmáticas destaca el hecho de su aplicabilidad tanto a delitos dolosos como a delitos imprudentes, reforzando así la unidad del sistema penal. Podemos decir, por lo tanto, que constituye un criterio que combina adecuadamente elementos propios de las tesis objetivo-materiales y de las tesis objetivo-formales, llegando a un justo equilibrio entre ambas. Sin embargo, su aplicación práctica no resultará sencilla, al menos no en todos $\operatorname{los} \operatorname{casos}^{21}$. Cuando nos enfrentamos a supuestos de hecho, el identificar qué acción o acciones son de autoría analizándolas conforme al criterio adoptado (la determinación objetiva y positiva del hecho) no será algo automático, como si de una fórmula matemática se tratase, sino que en ciertos casos nos encontraremos con serios problemas que necesitarán de un análisis complementario.

En aquellos casos en los que sólo existe un interviniente que lleva a cabo una determinada conducta que se relaciona causalmente con el resultado, el proceso de identificación del autor no ofrecerá grandes problemas. Lo mismo cabe decir cuando aun existiendo varios sujetos que intervienen en el hecho, aparece una de las acciones destacada frente al resto, desde el punto de vista jurídicopenal, sin necesidad de una valoración detallada. Sin embargo, la realidad práctica dista mucho de presentar las cosas de una forma tan simple, especialmente en el mundo actual en que las actividades profesionales (y no sólo) suponen la interactuación de numerosas personas que realizan conjuntamente conductas que pueden resultar lesivas de bienes jurídicos.

Desde la teoría de la determinación objetiva y positiva del hecho se ha propuesto un concepto de coautoría aplicable tanto al delito doloso como imprudente ${ }^{22}$,

concurrirá con independencia de la voluntad del agente si la conducta está objetivamente en condiciones de dominar, controlar o determinar el curso de los acontecimientos hacia el resultado y (...) efectivamente lo hace”. También, DÍAZ Y GARCÍA CONLLEDO, M., La autoría, cit., pág. 577, puntualiza que “(...) dado que considero que ni siquiera el dolo o la consciencia son elementos propios del dominio del hecho, es decir, fundamentadores específicamente de la autoría, mucho menos correcto me parece exigir otros elementos subjetivos [scil. ánimo o voluntad de autor o interés especial, que eran usados por los planteamientos subjetivos de la autoría], especialmente porque éstos, ni por sí solos, ni combinados con otros objetivos, tienen relación alguna con la realización del tipo". Por lo tanto, no se requiere el conocimiento de la situación de dominio, la finalidad o el dolo por parte del sujeto que realiza una acción que decide la producción del resultado delictivo. Al respecto, véase LUZÓN PEÑA, D.-M., "Alcance", cit., págs. 893 y s.; el mismo, Lecciones, cit., §18/50; DÍAZ Y GARCÍA CONLLEDO, M., La autoría, cit., págs. 628, 691; el mismo, "La autoría en Derecho penal”, cit., pág. 46; el mismo, "Un diálogo", cit., pág. 15; LUZÓN PEÑA, D.-M./DÍAZ Y GARCÍA CONLLEDO, M., "Determinación”, cit., pág. 67; los mismos, "Objektive positive Tatbestimmung", cit., pág. 589; los mismos, "Determinación objetiva", cit., págs. $104 \mathrm{y} \mathrm{s}$.

${ }^{21}$ En este sentido, DÍAZ Y GARCÍA CONLLEDO, M., La autoría, cit., pág. 677, advierte que “(...) en cuanto a la aplicación práctica del criterio, desde luego será difícil y complicada en diversos supuestos".

22 Cfr. LUZÓN PEÑA, D.-M., Lecciones, cit., §18/50. Sin embargo, no existe unanimidad sobre la aceptación o no de la coautoría imprudente, tal y como pone de manifiesto SÁNCHEZ LÁZARO, F.G., Intervención, cit., págs. 160 y s. El motivo de su rechazo en relación con los delitos imprudentes tiene que ver con el requisito subjetivo del "acuerdo", tradicionalmente exigido en esta forma de autoría; en Alemania, por ejemplo, la doctrina mayoritaria no admite la coautoría en los delitos imprudentes. Véase, 
que se diferencia de los defendidos desde otros sectores doctrinales no tanto por los requisitos que se exigen para constatar la coautoría (objetivo y subjetivo), sino por el contenido que dichos elementos deben poseer. En este contexto, esta teoría intenta resolver el problema de decidir cuándo se puede hablar, desde el punto de vista jurídicopenal, de una actuación en coautoría de dos o más sujetos y cuándo de una autoría accesoria de dos o más sujetos, que son dos categorías distintas que reciben tratamientos diversos y que llevan a consecuencias jurídicas, en ocasiones, opuestas, responsabilidad penal o impunidad.

En la exposición que sigue, expongo los conceptos de coautoría y de autoría accesoria desde la perspectiva de la teoría de la determinación objetiva y positiva del hecho, para a través de un análisis crítico cuestionar el papel que se le otorga al "acuerdo" desde esta posición doctrinal y proponer un entendimiento distinto del mismo que, en mi opinión, es más coherente con las bases conceptuales de esta teoría y que, por tanto, la refuerza.

Finalmente, cabe mencionar que el análisis de las consecuencias que se puedan extraer en el ámbito de la coautoría en los delitos dolosos será dejado para trabajos futuros.

\section{LA COAUTORÍA DESDE LA TEORÍA DE LA DETERMINACIÓN OBJETIVA Y POSITIVA DEL HECHO}

Desde la teoría de la determinación objetiva y positiva del hecho se ha dicho que "la coautoría supone la autoría de un conjunto de personas, ninguna de las cuales por sí sola resulta autora del hecho"23. Por lo tanto, la coautoría supondría una unidad de designio respecto de la ejecución conjunta de la conducta típica ${ }^{24}$. En este sentido, la teoría de la determinación objetiva y positiva del hecho identifica dos requisitos que se deben cumplir para poder hablar en estricto sentido de coautoría: a) uno primero, de

DURÁN SECO, I., La coautoría, cit., págs. 65 y s.; SÁNCHEZ LÁZARO, F.G., ob. cit., págs. 162 y s., 164 y ss.; MIR PUIG, S., PG, cit., pág. 409. Sobre la polémica de la admisión o no de la coautoría imprudente, ROSO CAÑADILLAS, R., Autoría, cit., pág. 562; LUZÓN PEÑA, D.-M., "Alcance”, cit., pág. 898 y s.; también en LUZÓN PEÑA, D.-M./DÍAZ Y GARCÍA CONLLEDO, M., "Determinación”, cit., págs. 83 y s.; los mismos, “Objektive positive Tatbestimmung”, cit., pág. 605; los mismos, "Determinación objetiva", cit., pág. 123; MIR PUIG, S., PG, cit., pág. 409.

${ }^{23}$ Sobre la coautoría y la aplicación de la teoría de la determinación objetiva y positiva del hecho a esta modalidad de autoría, cfr., por todos, DÍAZ Y GARCÍA CONLLEDO, M., La autoría, cit., págs. 651 y ss.; el mismo, "Dominio funcional, determinación positiva y objetiva del hecho y coautoría", LH-Roxin (Coimbra), 1995, págs. 305-307; el mismo, “Autoría mediata, coautoría y autoría accesoria”, EJB I, 1995 , 702 y ss.; el mismo, "Autoría”, cit., pág. 147; el mismo, "Autoría mediata, coautoría y autoría accesoria", $E P B, 2002$, págs. 173 y ss.; el mismo, "La autoría en Derecho penal”, cit., págs. 54 y ss.; el mismo, “Autoría y participación”, REJ 10 (2008), págs. 30 y ss.; el mismo, "La influencia”, cit., págs. 37 y ss.; el mismo, "Claus Roxin y la llamada autoría”, cit., págs. 376 y s.; DURÁN SECO, I., La coautoría, cit., passim; RODRÍGUEZ VÁZQUEZ, V., Responsabilidad, cit., págs. 383 y ss. En general, además, sobre la coautoría, GONZÁLEZ RUS, J. J., "Autoría”, cit., págs. 57 y ss.; DE LA MATA BARRANCO, N. J., "La participación del funcionario público en delitos comunes y especiales. Autoría y cooperación. Toma de decisiones en órganos colegiados", Delitos contra la Administración pública (ASÚA BATARRITA, Adela, ed.), Bilbao, 1997, págs. 99 y ss.; PÉREZ ALONSO, E. J., La coautoría, cit., passim. Finalmente, sobre la coautoría con imprudencia, véase, SOTO NIETO, F., "Coautoría”, cit., págs. 1774 y ss.; TRILLO NAVARRO, J. P., "Imprudencia en la cirugía estética. Coautoría y continuidad”, LLP 2007-43, págs. 18 y ss.; SÁNCHEZ LÁZARO, F. G., Intervención, cit., passim; RODRÍGUEZ VÁZQUEZ, V., Responsabilidad, cit., págs. 376 y ss.; CADAVID QUINTERO, A., Imprudencia, cit., págs. 353 y ss.

${ }^{24}$ Así, CADAVID QUINTERO, A., Imprudencia, cit., pág. 341. 
naturaleza objetiva, que se definiría como la co-determinación del hecho; y b) uno segundo, de naturaleza subjetiva, que contendría el acuerdo. Eso sí, es preciso tener en cuenta que un coautor es siempre un autor y que, por tanto, debe verificarse en todos los casos que el sujeto realiza la conducta que más directamente se enfrenta a la norma prohibitiva o imperativa contenida en el tipo penal ${ }^{25}$. Por último, cabe mencionar que ya desde las primeras exposiciones de la teoría de la determinación objetiva y positiva del hecho, LUZÓN PEÑA y DÍAZ Y GARCÍA CONLLEDO señalaban que "es en la coautoría donde se produce una mayor divergencia entre las concepciones mayoritarias, especialmente de la teoría del dominio del hecho, y la nuestra" ${ }^{26}$, tal y como se verá en la exposición que sigue.

\section{El requisito objetivo: la co-determinación del hecho}

Para afirmar la coautoría, la teoría de la determinación objetiva y positiva del hecho exige que se cumpla un primer requisito o elemento objetivo ${ }^{27}$, que DÍAZ Y GARCÍA CONLLEDO sintetiza afirmando, "habrá que precisar si lo realizado entre varios realmente domina el hecho, es decir, lo determina objetiva y positivamente; sólo la acción conjunta (es decir, el grupo de acciones vinculadas de tal modo que se pueda afirmar que constituyen una superior acción común) que posea características de la determinación objetiva y positiva del hecho fundamenta la coautoría, y hace que quienes la realizan sean auténticos coautores" ${ }^{28}$. De aquí se puede extraer la idea de que la constatación de la coautoría resulta de la comprobación cumulativa de varios subelementos o subrequisitos:

a) En primer lugar, se exige que concurran, al menos, dos acciones o más en la producción del hecho delictivo. Esta obviedad resulta ser el punto de partida ineludible para comenzar a plantearse si existe o no coautoría.

b) En segundo lugar, se debe comprobar la insuficiencia de cada una de ellas para producir el hecho por sí sola, ya que si una acción individual cumple con el criterio de la determinación objetiva y positiva del hecho se afirmará la autoría unipersonal y no cabría la coautoría. Con el cumplimiento de este criterio se establece una primera diferencia, en este caso respecto a la pluriautoría, caracterizada por la concurrencia de un conjunto de acciones que individualmente consideradas cumplen el requisito exigido para ser calificadas de autoría ${ }^{29}$.

\footnotetext{
${ }^{25}$ Sobre el fundamento normativo jurídico de la autoría para la determinación objetiva y positiva del hecho cfr. LUZÓN PEÑA, D.-M./DÍAZ Y GARCÍA CONLLEDO, M., "Objektive positive Tatbestimmung", cit., págs. 575 y ss.

${ }^{26}$ LUZÓN PEÑA, D.-M./DÍAZ Y GARCÍA CONLLEDO, M., "Determinación", cit., págs. 69 y s.; DÍAZ Y GARCÍA CONLLEDO, M., "Claus Roxin y la llamada autoría”, cit., págs. 376 y s.

${ }^{27}$ Las razones por la que comenzar por el elemento objetivo y no por el subjetivo se pueden ver en DURÁN SECO, I., La coautoría, cit., págs. 61 y ss.

${ }^{28}$ DÍAZ Y GARCÍA CONLLEDO, M., La autoría, cit., pág. 690; el mismo, "Autoría mediata", cit., págs. 173 y ss.; en el mismo sentido, LUZÓN PEÑA, D.-M., "Alcance", cit., pág. 906 y s.; el mismo, Curso, cit., pág. 510; LUZÓN PEÑA, D.-M./DÍAZ Y GARCÍA CONLLEDO, M., "Determinación", cit., pág. 83; los mismos, "Objektive positive Tatbestimmung", cit., pág. 605; los mismos, "Determinación objetiva", cit., págs. 122 y s.; BOLEA BARDÓN, C., La cooperación, cit., pág. 31, señala que "se trata de una co-realización del tipo que permite hacer responder a cada uno de forma independiente por el hecho global como hecho propio". Véase, también, RODRÍGUEZ VÁZQUEZ, V., Responsabilidad, cit., págs. 384 y s.

${ }^{29}$ ROSO CAÑADILLAS, R., Autoría, cit., pág. 561; en la misma línea, DÍAZ Y GARCÍA CONLLEDO, M., “Autoría mediata”, cit., pág. 173; también, DURÁN SECO, I., La coautoría, cit., pág. 285.
} 
c) En tercer lugar, el último elemento que completa el círculo y permite decir que se cumple el requisito objetivo de la coautoría es la comprobación de que la conjunción de las acciones realizadas por distintas personas, y sólo esa conjunción, es la que co-determina objetiva y positivamente el hecho.

En definitiva, el criterio elaborado para identificar la autoría se debe cumplir, al igual que en los casos de autoría unipersonal inmediata (y mediata), también aquí, con la única diferencia de que en este supuesto esa cualidad, la de determinar el si y el cómo del hecho, debe recaer en la suma de dos o más acciones ${ }^{30}$. Por lo tanto, no basta con la concurrencia de dos o más acciones, cuyas aportaciones al hecho pueden tener cierta relevancia penal, sino que se exige una necesidad mutua entre, al menos, dos acciones, de manera que su unión, sin requerimiento de ninguna otra, pero sin poder prescindir de aquélla de la que depende, es lo que conduce al resultado final. De esta forma se proponen criterios materiales para llevar a cabo una segunda diferenciación, la que permite distinguir no sólo entre conductas de autoría y complicidad sino, lo que es más difícil, al autor del cooperador necesario ${ }^{31}$.

En el proceso de restricción del concepto de autor, en el que la teoría del dominio del hecho parecía aportar los criterios necesarios para concretar la coautoría frente a las intervenciones de los cooperadores necesarios, la teoría de la determinación objetiva y positiva del hecho da una "vuelta de tuerca" trazando con mayor precisión la delgada línea roja que separa al coautor del cooperador necesario ${ }^{32}$. Desde este segundo punto de vista se dice que no basta con que el sujeto pueda interrumpir, con la simple retirada de su contribución, el hecho. Es cierto que la acción así definida se revela especialmente importante o "esencial", sin embargo, no posee el control definitivo sobre el mismo, no puede decidir el resultado final, que depende de otra conducta, de la conducta del autor. Para poder decir que un sujeto es coautor del delito debe realizar una

\footnotetext{
${ }^{30}$ DÍAZ Y GARCÍA CONLLEDO, M., La autoría, cit., pág. 677; el mismo, “Autoría mediata”, cit., pág. 174; LUZÓN PEÑA, D.-M./DÍAZ Y GARCÍA CONLLEDO, M., "Determinación”, cit., pág. 74; los mismos, "Objektive positive Tatbestimmung", cit., pág. 596; los mismos, "Determinación objetiva", cit., pág. 112; siguiendo a estos autores, ROSO CAÑADILLAS, R., Autoría, cit., pág. 580; DURÁN SECO, I., La coautoría, cit., pág. 279; RODRÍGUEZ VÁZQUEZ, V., Responsabilidad, cit., págs. 384 y ss.

${ }^{31}$ Sobre la distinción entre participación y coautoría, desde la teoría de la determinación objetiva y positiva del hecho, véase, por todos, DÍAZ Y GARCÍA CONLLEDO, M., "Un diálogo", cit., págs. 15 y $\mathrm{S}$.

32 En el mismo sentido, SÁINZ-CANTERO CAPARRÓS, J.E., La codelincuencia, cit., pág. 23; sobre la evolución histórica de la teoría del dominio del hecho, así como los autores que defienden esta postura y los matices diferenciadores entre todos ellos, se puede consultar al propio ROXIN, C., Autoría, cit., págs. 81 y ss. También se puede consultar una relación exhaustiva de autores en DÍAZ Y GARCÍA CONLLEDO, M., La autoría, cit., pág. 548; GIMBERNAT ORDEIG, E., Autor, cit., págs. 123 y ss.; SÁNCHEZ LÁZARO, F.G., Intervención, cit., págs. 49 y s. Entre los autores españoles que siguen esta teoría se puede destacar: HERNÁNDEZ PLASENCIA, J.U., La autoría, cit., págs. 62 y ss.; LÓPEZ BARJA DE QUIROGA, J., Autoría, cit., pág. 47; CHOCLÁN MONTALVO, J.A., "La autoría y la participación", $L L$ 1996-1, pág. 1643; MUÑOZ CONDE F./GARCÍA ARÁN, M., Derecho Penal, $P G, 9^{\mathrm{a}}$ ed., Valencia, 2015, págs. 435 y s. PÉREZ ALONSO, La coautoría, cit., pág. 138, señala: “(...) dicha construcción es defendida por la doctrina alemana de forma mayoritaria y por un sector considerable de la doctrina española que, con la entrada en vigor del nuevo $\mathrm{CP}$, se ha convertido también en la teoría mayoritariamente defendida". Finalmente, sobre las críticas a la teoría del dominio, véase, Cfr. DÍAZ Y GARCÍA CONLLEDO, M., "La autoría en Derecho penal”, cit., pág. 43.
} 
aportación que no sólo le dé el poder de decidir cuándo "no" se produce el hecho delictivo sino cuándo sín si $^{33}$.

Las consecuencias de esta postura se pueden ver a través de dos ejemplos paradigmáticos manejados por la doctrina. En el supuesto del que vigila en un robo, se sostiene que "por mucho que el sujeto vigile y vigile, si nadie toma la cosa, no habrá robo, es decir está en manos de otro u otros la realización del tipo; es decir, supuesto que nadie haya interrumpido el hecho anteriormente, el vigilante, al realizar su acción, no roba, porque roba quien toma las cosas, sea uno o varios; en cambio, en el caso de éstos, supuesto que nadie haya interrumpido el hecho antes, en cuanto realizan su acción, determinan positivamente el hecho; es decir, que el cooperador necesario depende totalmente del autor o autores, mientras que éste o éstos sólo dependen de aquél en un sentido negativo (dependen en cuanto que, para poder actuar, precisan de la actuación del cooperador necesario, pero, supuesta ésta, el hecho queda totalmente en sus manos)" ${ }^{\prime 34}$. El mismo razonamiento se aplica respecto del caso de quien sujeta a la víctima mientras otro la apuñala ${ }^{35}$. De esta forma, el ámbito de aplicación de la coautoría se reduce considerablemente frente a otras concepciones, lo que permite mantener las ventajas de un concepto restrictivo de autor ${ }^{36}$.

\section{El requisito subjetivo: el acuerdo}

Además del requisito objetivo, se exige la presencia de un requisito subjetivo, identificado con el acuerdo que debe mediar entre los intervinientes que han realizado una acción que cumple con los criterios anteriormente señalados. La exigencia de este elemento subjetivo no es exclusiva de la teoría de la determinación objetiva y positiva del hecho. Tradicionalmente, la mayoría de la doctrina ha visto en el "acuerdo" el elemento característico y diferenciador de la coautoría ${ }^{37}$, si bien es cierto que su

\footnotetext{
${ }^{33}$ Cfr. ROSO CAÑADILLAS, R., Autoría, cit., pág. 577; DURÁN SECO, I., La coautoría, cit., pág. 284; en el mismo sentido, BOLEA BARDÓN, C., La cooperación, cit., pág. 48.

${ }^{34}$ DÍAZ Y GARCÍA CONLLEDO, M., La autoría, cit., pág. 670; el mismo, “Autoría mediata”, cit., pág. 175; LUZÓN PEÑA, D.-M./DÍAZ Y GARCÍA CONLLEDO, M., "Determinación”, cit., pág. 72; los mismos, "Objektive positive Tatbestimmung", cit., pág. 593; los mismos, "Determinación objetiva", cit., pág. 110; en el mismo sentido respecto a este ejemplo, BOLEA BARDÓN, C., La cooperación, cit., págs. 55 y s.

35 Véase DÍAZ Y GARCÍA CONLLEDO, M., La autoría, cit., pág. 670; DURÁN SECO, I., La coautoría, cit., págs. 282 y ss.; BOLEA BARDÓN, C., La cooperación, cit., págs. 53 y ss., para quien, constituirá coautoría, siempre que se cumplan los requisitos objetivos y subjetivos señalados, la confluencia de acciones típicamente ejecutivas y de actos ejecutivos no típicos, pero directamente vinculados a la acción descrita por el tipo.

36 Véase DÍAZ Y GARCÍA CONLLEDO, M., "Autoría mediata", cit., pág. 174; el mismo, "La influencia”, cit., págs. 38 y ss.; LUZÓN PEÑA, D.-M./DÍAZ Y GARCÍA CONLLEDO, M., "Determinación", cit., pág. 74; los mismos, “Objektive positive Tatbestimmung”, cit., pág. 596; los mismos, "Determinación objetiva", cit., pág. 112.

${ }^{37}$ Cfr. DÍAZ Y GARCÍA CONLLEDO, M., La autoría, cit., págs. 653 y ss., contempla una detallada relación de autores alemanes y españoles que exigen este requisito para hablar de autoría. Ahora bien, esta exigencia no es unánime, como se puede ver en los autores relacionados nuevamente por DÍAZ Y GARCÍA CONLLEDO, M., ob. cit., 657 y ss.; también en Autoría, cit., pág. 580; GUTIÉRREZ RODRÍGUEZ, M., La responsabilidad penal del coautor, Valencia, 2001, págs. 126 y ss., con una abundante bibliografía; BOLEA BARDÓN, C., La cooperación, cit., págs. 31, 37 y ss. En España, recientemente sostiene la innecesariedad del acuerdo SÁNCHEZ LÁZARO, F. G., Intervención, cit., págs. 193 y ss.; GARCÍA DEL BLANCO, M. V., La coautoría en Derecho penal, Valencia, 2006, págs. 432 y s., 636 y s., 639, 647, 687, 695.
} 
conceptuación y desarrollo en relación con la coautoría con imprudencia ${ }^{38}$ se debe, en gran parte, a la teoría propuesta por LUZÓN PEÑA, completada por DÍAZ Y GARCÍA CONLLEDO.

Las razones por las que desde la teoría de la determinación objetiva y positiva del hecho se exige el acuerdo para afirmar la coautoría son reconducibles a dos: posibilita la imputación recíproca ${ }^{39}$ y permite referirse a una acción conjunta ${ }^{40}$.

En primer lugar, el acuerdo ha sido y es visto como el elemento que permite hacer responder a cada uno de los intervinientes por las acciones realizadas por los demás sujetos que determinan el hecho, respetando así el principio de responsabilidad personal, en función del cual no se puede responsabilizar a nadie por hechos ajenos sino sólo por hechos propios. Desde este punto de vista, el acuerdo aparece configurado como un elemento constitutivo de la coautoría, sin el cual no sólo no se puede decir que hay coautoría, sino que no se puede hacer responder a cada uno de los intervinientes por el hecho realizado. Esta idea es plasmada, en el ámbito de la coautoría dolosa, por DÍAZ Y GARCÍA CONLLEDO, señalando que "es correcto exigir ese acuerdo común mínimo (en el sentido de que puede ser tácito) en la coautoría, por diversas razones. Una de ellas es la derivada del mal llamado principio de culpabilidad -y que debería llamarse principio de responsabilidad subjetiva- (o necesidad de que exista también un injusto subjetivo), pues, al igual que en cualquier otra forma de intervención, al sujeto no se le puede hacer responder, al menos a título de dolo, por aquello que no conoce o no quiere (por ejemplo, por los excesos de otro interviniente). (...) el acuerdo en la coautoría permite hacer responder a cada uno de los coautores por lo que hacen los demás" ${ }^{\prime 1}$. Estas afirmaciones son trasladadas intactas a la coautoría con imprudencia por ROSO CAÑADILLAS, que además de reproducirlas señala, “éste [scil. el acuerdo] debe ser necesario, ya que de lo contrario no se podría aplicar el principio propio de la coautoría; me estoy refiriendo al de la imputación recíproca. Gracias a este principio a cada coautor se le puede imputar lo realizado por el resto de coautores, pero para ello es necesario que haya existido el acuerdo en realizar la acción descuidada"42.

En segundo lugar, se afirma que el acuerdo lleva a referirse a varias acciones como una acción "con mayúsculas", conjunta. Lo que supone una diferencia cualitativa respecto a los casos en los que no existe tal acuerdo, en los que sólo se puede hablar de

\footnotetext{
${ }^{38}$ Utilizo la expresión "coautoría con imprudencia" en lugar de la clásica denominación "coautoría imprudente" para fijar, también conceptualmente, la distinción que entiendo debe existir en el análisis del tipo objetivo y del tipo subjetivo, según la propuesta que hago en este trabajo.

${ }^{39}$ Cuestionándose el principio de imputación recíproca, cfr. BOLEA BARDÓN, C., La cooperación, cit., págs. 33, 49.

${ }^{40}$ DÍAZ Y GARCÍA CONLLEDO, M., La autoría, cit., págs. 443, 443 n. 99, 579; el mismo, "Autoría", cit., pág. 146; el mismo, "La influencia", cit., pág. 35, ha destacado y defendido la existencia de un elemento subjetivo en la coautoría y, en general, en la teoría de la determinación objetiva y positiva del hecho. Afirma que "no se trata de que desliguemos plenamente el aspecto subjetivo de la autoría ni le dejemos de dar importancia. Simplemente intentamos destacar lo que consideramos que es peculiar de la autoría, sin que ello signifique en absoluto que no pueda influir en cuestiones relativas a la autoría y a la participación". Cfr. también, LUZÓN PEÑA, D.-M./DÍAZ Y GARCÍA CONLLEDO, M., "Objektive positive Tatbestimmung", cit., pág. 596.

${ }^{41}$ DÍAZ Y GARCÍA CONLLEDO, M., La autoría, cit., págs. 655 y s.; LUZÓN PEÑA, D.-M./DÍAZ Y GARCÍA CONLLEDO, M., "Determinación", cit., págs. 71, 74; los mismos, "Objektive positive Tatbestimmung", cit., págs. 593, 596; los mismos, "Determinación objetiva", cit., págs. 109, 112; BOLEA BARDÓN, C., La cooperación, cit., pág. 39.

${ }^{42}$ ROSO CAÑADILLAS, R., Autoría, cit., pág. 587.
} 
una "suma de acciones"43, y que tendrían que ser reconducidos a la llamada "autoría accesoria". Por lo tanto, el acuerdo desempeña un papel diferenciador entre dos especies, la coautoría y la autoría accesoria, de un mismo género, la concurrencia de imprudencias. En efecto, por una parte, "el acuerdo con división del trabajo o acumulación de esfuerzos es lo que permite hablar de una acción conjunta formada por actos parciales; cuando esos actos parciales no serían suficientes por sí solos para determinar objetiva y positivamente el hecho, pero sí la conjunción de ellos. Para poder hablar de una acción determinante es necesario que la misma presente una conexión, que se explica estructuralmente por la existencia de un acuerdo con reparto de funciones o suma de esfuerzos" 44 ; por otra, "en la autoría accesoria los sujetos no actúan con acuerdo, pero sus aportaciones determinan el hecho conjuntamente, es decir, codeterminan el hecho al igual que en la coautoría"45.

\section{AUTORÍA ACCESORIA VS. COAUTORÍA Y EL CRITERIO UTILIZADO PARA ATRIBUIR EL HECHO A LOS VARIOS INTERVINIENTES}

La autoría accesoria se caracteriza por cumplir el requisito objetivo que se debe dar en los supuestos de coautoría. Es decir, concurren varias conductas imprudentes de manera que la unión de todas y cada una de ellas es la que produce el hecho ${ }^{46}$. Desde este punto de vista, esto es, atendiendo al elemento o requisito objetivo, la coautoría y la autoría accesoria son plenamente coincidentes. La diferencia entre ambas figuras se plantea, sin embargo, en relación con el elemento subjetivo. En la autoría accesoria no existe un acuerdo entre los sujetos que realizan las aportaciones objetivamente determinantes del hecho, de tal forma que la concurrencia de esas acciones en el tiempo y en el espacio, podríamos decir que, en muchos casos, es fruto del azar o de la casualidad $^{47}$. En definitiva, en la autoría accesoria dos acciones, o más, son las que sumadas determinan la producción del hecho penalmente relevante, pero falta el acuerdo entre los sujetos intervinientes.

Por su parte, el acuerdo es exigido en la coautoría para poder imputar recíprocamente el resultado lesivo a las conductas concurrentes, de manera que, como advierte SÁNCHEZ LÁZARO, "si estos autores fueran consecuentes, deberían dejar impunes —consecuencia político-criminal inasumible - todos los supuestos que reconducen a través de esta figura, 'ya que no es posible castigar por tentativas imprudentes, y esto es lo que constituyen las aportaciones al hecho de los autores accesorios que no crean todo el riesgo que produce el resultado",48. Pues bien, en una sociedad como la actual, en la que concurren una pluralidad de personas en la realización de la mayoría de las actividades profesionales y no profesionales (ocio, desplazamientos, etc.), siendo más que probable, y en determinados sectores ocurre con

\footnotetext{
${ }^{43}$ DÍAZ Y GARCÍA CONLLEDO, M., La autoría, cit., pág. 657.

44 DÍAZ Y GARCÍA CONLLEDO, M., La autoría, cit., pág. 656; LUZÓN PEÑA, D.-M./DÍAZ Y GARCÍA CONLLEDO, M., "Determinación”, cit., págs. 71, 75; los mismos, "Objektive positive Tatbestimmung", cit., págs. 593, 596; los mismos, "Determinación objetiva”, cit., págs. 109, 112; en sentido similar, GARCÍA DEL BLANCO, M. V., La coautoría, cit., págs. 379 y s.

${ }^{45}$ ROSO CAÑADILLAS, R., Autoría, cit., pág. 590.

${ }^{46}$ Véase LUZÓN PEÑA, D.-M., “Alcance”, cit., págs. 898 y s.; el mismo, Curso, cit., pág. 510; LUZÓN PEÑA, D.-M./DÍAZ Y GARCÍA CONLLEDO, M., "Determinación”, cit., pág. 84; los mismos, "Objektive positive Tatbestimmung”, cit., págs. 605 y ss.; los mismos, "Determinación objetiva”, cit., pág. 124; ROSO CAÑADILLAS, R., Autoría, cit., pág. 590.

47 Véase GUTIÉRREZ RODRÍGUEZ, M., La responsabilidad, cit., pág. 183.

${ }^{48}$ SÁNCHEZ LÁZARO, F.G., Intervención, cit., págs. 198 y s.
} 
relativa frecuencia, que coincidan varias acciones descuidadas, es decir, varios sujetos que infringen el deber de cuidado que les correspondía observar, sin que medie acuerdo entre ellos (en muchos casos lo que existe es un desconocimiento absoluto del otro actor) que acaban produciendo un resultado lesivo, una solución como la apuntada por este autor sería tremendamente insatisfactoria e injusta. No se comprendería la razón en función de la cual se establece una diferencia de trato para los sujetos que puestos de acuerdo causan imprudentemente un resultado lesivo, frente a aquellos otros que, realizando las mismas acciones, infringiendo los mismos deberes de cuidado y produciendo el mismo resultado, han actuado sin acuerdo, o con pleno desconocimiento de la presencia del otro. Una diferencia de trato, por lo demás, tan exagerada, pues de la exigencia de responsabilidad penal como (co)autores de un delito, para los primeros, se pasaría a la impunidad para los segundos que actuarían como autores accesorios.

Son numerosos los supuestos prácticos de autoría accesoria, sobre todo en el ámbito de la circulación, utilizados por la doctrina para poner de manifiesto lo señalado anteriormente. Por ejemplo, el caso de dos vehículos que circulan temerariamente por una autopista y ocasionan un accidente donde fallece una tercera persona, sin que los conductores se conozcan o se hayan puesto de acuerdo previamente ${ }^{49}$. En el supuesto de que el resultado no pueda ser atribuido individualmente a alguno de ellos a título de autor, sino que sólo pueda ser reconducido a la suma de las dos acciones, dado que la falta de acuerdo impide imputar recíprocamente el riesgo generado por cada una de las acciones, el hecho quedará impune. Con lo cual, podría incluso afirmarse que "el que conduce peligrosamente esperará que, en caso de accidente, concurra alguna otra imprudencia en su producción para asegurarse la impunidad, ya que, en la medida en que no se le puede imputar totalmente el resultado, dado que para ello es preciso admitir la imputación recíproca entre los distintos conductores que originan el mismo, ni individualizar en él los efectos de su contribución, quedará impune"50.

Otro caso es el del conductor de un coche que al llegar a un cruce no respeta la señal de "stop" y se introduce sin detenerse en la vía preferente, y otro automovilista que llega por esta vía preferente lo hace desatento y a gran velocidad, sin respetar el límite de velocidad que había al acercarse al cruce, por lo que chocan ambos vehículos $^{51}$. En este supuesto, "los dos sujetos co-determinan el hecho, sólo que cada uno no se ha puesto de acuerdo con el otro para llevar a cabo su conducta infractora de la norma de cuidado, por lo que este caso de concurrencia de imprudencias será de autoría accesoria. Sus actuaciones por sí solas no producirían el hecho típico, pero su unión ha llevado a la producción del resultado" 52 .

Según la doctrina mayoritaria, entonces, la falta de acuerdo debería llevar a la impunidad, sin embargo, desde la teoría de la determinación objetiva y positiva del hecho, en la autoría accesoria se llega a la misma solución penal que en la coautoría, es decir, se exige responsabilidad penal a título de autor a cada uno de los intervinientes. ¿Cómo? ¿De qué forma se puede imputar recíprocamente si no hay acuerdo? A través

\footnotetext{
49 Véase SÁNCHEZ LÁZARO, F.G., Intervención, cit., pág. 195.

${ }^{50}$ SÁNCHEZ LÁZARO, F.G., Intervención, cit., pág. 195.

51 Véase LUZÓN PEÑA, D.-M., Curso, cit., pág. 510; LUZÓN PEÑA, D.-M./DÍAZ Y GARCÍA CONLLEDO, M., "Determinación”, cit., págs. 84 y s.; los mismos, “Objektive positive Tatbestimmung”, cit., págs. 605 y s.; los mismos, "Determinación objetiva”, cit., págs. 124 y s.; reproduce este mismo ejemplo ROSO CAÑADILLAS, R., Autoría, cit., págs. 588 y s.

${ }^{52}$ ROSO CAÑADILLAS, R., Autoría, cit., págs. 590 y s.
} 
de la imputación objetiva, "ya que es previsible (requisito de la idoneidad de la acción) en muchos supuestos de la vida diaria y sobre todo en el tráfico rodado que a la primera conducta infractora se le sume otra posterior concurriendo en la producción del resultado y también se dé de este modo la relación de riesgo, con lo que sí estaremos ante un autor de un delito imprudente consumado" ${ }^{\text {. }}$. En este sentido se expresa LUZÓN PEÑA al señalar que “en la autoría accesoria imprudente serán mucho más frecuentes los supuestos en que sí le sea objetivamente imputable el resultado -a las dos o al menos a una de las conductas-, por ser objetivamente previsible la posible concurrencia de otra conducta (imprudente o diligente) que co-determine el curso del hecho, es decir, por ser adecuada esa forma (curso causal) de producirse el resultado, y por suponer éste, aunque su causación haya sido en conjunción con otra conducta, la realización de un riesgo inherente a aquella conducta imprudente y que la norma pretendía evitar" ${ }^{\prime 5}$.

En la misma línea DÍAZ Y GARCÍA CONLLEDO, reproduciendo las reflexiones de su maestro, señala que "cuando las conductas concurrentes sean todas de autoría (es decir, excluidos los casos de mero favorecimiento a que me he referido), el que exista responsabilidad penal "dependerá de si hay o no imputación objetiva del resultado a cada una de las conductas imprudentes (de autoría accesoria) concurrentes", y habrá casos en que no se den los criterios de imputación objetiva del resultado. Creo que LUZÓN tiene razón, si bien sigo pensando que, en los casos de autoría accesoria imprudente, va a ser muy frecuente la posibilidad de imputar objetivamente el resultado" $" 55$.

En mi opinión estos autores tienen toda la razón y, al igual que ellos, creo que es posible basar la imputación, de uno o de ambos, en la autoría accesoria a través de la institución de la imputación objetiva ${ }^{56}$, haciéndolos autores, prescindiendo del acuerdo entre los intervinientes, y estoy plenamente de acuerdo con la afirmación de que esa posibilidad se va a dar con frecuencia. Esta posición creo que se puede reforzar acudiendo al principio de confianza y a sus presupuestos de aplicación ${ }^{57}$, como explico brevemente a continuación.

\footnotetext{
${ }^{53}$ ROSO CAÑADILLAS, R., Autoría, cit., pág. 593.

${ }^{54}$ LUZÓN PEÑA, D.-M., "Alcance”, cit., pág. 899; el mismo, Curso, cit., pág. 510; LUZÓN PEÑA, D.M./DÍAZ Y GARCÍA CONLLEDO, M., “Determinación”, cit., pág. 85; los mismos, "Objektive positive Tatbestimmung”, cit., pág. 606; los mismos, "Determinación objetiva”, cit., págs. 124 y s.

${ }^{55}$ DÍAZ Y GARCÍA CONLLEDO, M., La autoría, cit., pág. 636.

${ }^{56}$ Acerca de las relaciones entre autoría e imputación objetiva en la teoría de la determinación objetiva y positiva del hecho, véase DÍAZ Y GARCÍA CONLLEDO, M., La autoría, cit., pág. 495, n. 270; el mismo, "Autoría", cit., pág. 146; el mismo, "La influencia”, cit., págs. 29 y s. Y, en todo caso, sobre el rechazo a suplantar el juicio de autoría por el de imputación objetiva o a determinar la autoría y la participación mediante la imputación objetiva, véase DÍAZ Y GARCÍA CONLLEDO, M., La autoría, cit., págs. 494 y ss.; HERNÁNDEZ PLASENCIA, J.U., "Imputación objetiva versus dominio del hecho", LH-Cerezo, 2002, págs. 735 y ss.; GÓRRIZ ROYO, E., El concepto de autor en Derecho penal, Valencia, 2002, pág. 374.

${ }^{57}$ El principio de confianza es enunciado por la doctrina penal con distintas formulaciones y para diversos ámbitos de actividad. Una definición con carácter general de este principio se puede ver en STRATENWERTH, G., "Arbeitsteilung und ärztliche Sorgfaltspflicht”, FS-Eb. Schmidt, págs. 386 y ss.; el mismo, Derecho Penal, PG, I: El hecho punible, Madrid, 1982, § 15-1154; el mismo, Strafrecht, AT, I: Die Straftat, 4 a ed., München, 2000, § 15-65: "por regla general, no se responde por la falta de cuidado ajeno, sino que el derecho autoriza a confiar en que los otros cumplirán sus deberes de cuidado"; BOCKELMANN, P./VOLK, K., Strafrecht, AT, 4ª ed., München, 1987, págs. 161 y s.; JORGE BARREIRO, Al., "La imprudencia", cit., pág. 252; LÓPEZ BARJA DE QUIROGA, J., "El delito imprudente en el Código Penal de 1995", PJ 40-1995, págs. 232, 234; el mismo, Derecho penal. PG. II.
} 
Introducción a la teoría jurídica del delito; IV. Las consecuencias jurídicas del delito. El Derecho penal de ejecución, Madrid, 2002, pág. 289; BRINKMANN, B., Der Vertrauensgrundsatzt als eine Regel der Erfehrung. Eine Untersuchung am Beispiel des Lebensmittelstrafrechts, Berlin, 1996, págs. 138 y ss.; FEIJÓO SÁNCHEZ, B., "El principio de confianza como criterio normativo de imputación en el Derecho penal: fundamento y consecuencias dogmáticas", $R D P C r$ 1-2000, pág. 103; el mismo, Resultado lesivo e imprudencia: estudio sobre los límites de la responsabilidad penal por imprudencia y el criterio del "fin de protección de la norma de cuidado”, Barcelona, 2001, pág. 318; ZAFFARONI, R. E./ALAGIA, A./SLOKAR, A. W., Derecho penal, $P G, 3^{\text {a }}$ ed., Buenos Aires, 2005, pág. 532; MARAVER GÓMEZ, M., El principio de confianza en Derecho penal. Un estudio sobre la aplicación del principio de autorresponsabilidad en la teoría de la imputación objetiva, Pamplona, 2009, passim; RODRÍGUEZ VÁZQUEZ, V., Responsabilidad, cit., págs. 216 y ss. Por su parte, GÓMEZ RIVERO, M.C., La responsabilidad penal del médico, $2^{\mathrm{a}}$ ed., Valencia, 2008, pág. 395, afirma que "cada participante en una actividad puede y tiene que confiar en que la actuación del resto de los intervinientes será correcta, de tal modo que sólo cuando existan motivos fundados para desconfiar en la conformidad a cuidado de la actuación de los terceros, podrá dejar de invocarse dicha presunción por el resto de los intervinientes"; VILLACAMPA ESTIARTE, C., Responsabilidad, cit., pág. 147, considera que "el postulado básico del principio reza que todos pueden confiar en la conducta correcta de los demás, salvo que especiales circunstancias indiquen lo contrario, ello significa que no está permitida la confianza cuando se conozca o se pueda prever la infracción del deber de cuidado del otro interviniente, o cuando no se pueda confiar en la corrección de la conducta del mismo por tratarse de persona con capacidades inferiores a las normales - por ser un niño o un anciano-, o bien, y ésta es la limitación que mayor importancia tiene en el objeto de investigación de este trabajo cuando quien confía lo hace indebidamente, entre otras razones por haberse comportado de forma contraria a deber. Esto es, por mor de la última de las referidas excepciones, quien en su comportamiento no observa el cuidado debido no puede esperar que los demás lo hagan. En relación con el tráfico viario se puede encontrar enunciado en CORCOY BIDASOLO, M., El Delito imprudente. Criterios de imputación del resultado, Barcelona, 1989, pág. 327, afirma que "la jurisprudencia ha elaborado el principio de confianza, especialmente, en relación con el tráfico viario. Según el principio de confianza el participante en el tráfico puede confiar en que los demás se comporten también correctamente, mientras no le conste lo contrario por circunstancias especiales del caso. No obstante, aunque desarrollado en el tráfico, el principio de confianza puede aplicarse en todas aquellas actividades en que concurren distintas conductas peligrosas en una misma situación. El principio de confianza despliega su eficacia en aquellos supuestos en que con la actuación infractora de un sujeto se entremezclan otros participantes en la actividad de que se trate, que se encuentran inmersos en el mismo peligro creado por la infracción”; LUZÓN PEÑA, D.-M., Curso, cit., págs. 504 y s., señala que "todo conductor que actúe con la debida diligencia (aunque parte de la jurispr. y doc. quieren admitirlo también aunque infrinja el cuidado objetivamente debido) puede confiar en principio en que los demás participantes en el tráfico se comportarán a su vez con el cuidado debido, a no ser que en virtud de circunstancias del caso concreto deba tener motivos para pensar lo contrario: o porque ya se vea que otra persona comienza a actuar imprudentemente, o porque en virtud de lo que el TS llama principio de defensa los otros participantes en el tráfico sean personas de las que por experiencia cabe esperar reacciones o conductas anormales o descuidadas, como niños, ancianos, incapacitados o personas ebrias (máxime si intervienen como peatones o ciclistas, que están más desprotegidos)"; ROXIN, C., Strafrecht, AT: Grundlagen, der Aufbau de Verbrechenslehre, Bd. 1, 4 ed., München, 2006 (Derecho Penal, PG: Fundamentos. La estructura de la teoría del delito, Madrid, 1997), § 24 21, indica que "el principio de confianza hoy reconocido sobre todo en el Derecho penal de la circulación es un principio que sirve para la negación de un incremento del peligro inadmisible. En su forma más general afirma que quien se comporta debidamente en la circulación puede confiar en que otros también lo hagan, siempre y cuando no existan indicios concretos para suponer lo contrario"; el mismo, Política criminal, 1992, 98 y s. En relación con la actividad médico-sanitaria, ROMEO CASABONA, C.M., El médico y el derecho penal I: la actividad curativa (licitud y responsabilidad penal), Barcelona, 1981, pág. 248, observa que "al que participa en el tráfico le cabe confiar en que el otro partícipe se comportará también en forma correcta, en tanto que no se le manifieste claramente lo contrario o concurran en este sentido circunstancias especiales. (...) La aplicación del principio de confianza al trabajo en equipo, o actuación conjunta mediante la distribución de funciones, puede expresarse así: el médico puede en principio confiar en que sus colaboradores actuarán cuidadosamente en la ejecución de los cometidos transferidos a ellos cuando se hallan correspondientemente preparados y adiestrados y son supervisados en general dentro de unos límites razonables"; el mismo, El médico ante el Derecho, Madrid, 1985, pág. 76; JORGE BARREIRO, Ag., La imprudencia, cit., pág. 119; el mismo, "Aspectos básicos de la imprudencia punible en la actividad médico-quirúrgica", $E P C r$ XIV 1989-90, pág. 171; el mismo, "Nuevos aspectos de la 
En los supuestos de actividades en las que participan varias personas, por ejemplo, tráfico rodado, construcción, ámbito médico, la regla general, que permite su desarrollo, es la vigencia del principio de confianza, de manera que quien actúa correctamente, es decir, cumpliendo con los deberes de cuidado que le corresponde observar, podrá pensar que los demás también obrarán de la misma forma. Por lo tanto, como regla general no le será exigible prever o podrá no prever, quien obra conforme a Derecho, que su conducta pueda concurrir con la de otro sujeto en la producción de un resultado lesivo. Ahora bien, la vigencia del principio de confianza no es ilimitada ${ }^{58}$. Entre todos los límites trazados por la doctrina penal, destaca, a los efectos que aquí

imprudencia jurídico-penal en la actividad médica: la culpa en el equipo médico-quirúrgico", VV. AA, Responsabilidad del personal sanitario (actas del seminario conjunto sobre la responsabilidad del personal sanitario celebrado en Madrid los días 14, 15 y 16 de noviembre de 1994) (Martínez Martín, coord.), Madrid, 1995, pág. 364, señala que "el principio de confianza aplicado a la actividad médicoquirúrgica implica que el cirujano puede, en principio, confiar en que sus colaboradores (anestesista, ayudantes, enfermeras) se comportarán diligentemente, en tanto no concurran en el caso concreto circunstancias especiales -como la falta de cualificación, inexperiencia, ineptitud, descuidos graves-, reconocibles, que le hagan pensar en lo contrario"; SILVA SÁNCHEZ, J.-M., "Aspectos de la responsabilidad penal por imprudencia del médico anestesista. La perspectiva del Tribunal Supremo", DS 2-1994, pág. 58, considera que "cada especialista puede contar en principio con la colaboración correcta del colega de la otra especialidad; sólo excepcionalmente, esto es, cuando consta la comisión de una infracción del deber de cuidado por el otro o existen dudas sobre su cualificación o fiabilidad, surge un deber de cuidado (que algunos denominan secundario), cuyo incumplimiento puede conducir a imputar el resultado lesivo al cirujano, por ejemplo, que ha confiado, ya indebidamente, en una conducta diligente del anestesista"; el mismo, Medicinas alternativas, 1999, 28, "cada uno puede, pues, contar con que el otro ha empleado la debida diligencia en la realización de las funciones que le son propias"; en el mismo sentido, ALMELA VICH, C., "La responsabilidad penal del médico y del cirujano", PJ 48-1997, pág. 244; CEREZO MIR, J., Curso de Derecho Penal español, PG, t. II: Teoría jurídica del delito, 6 a ed., Madrid, 1998, págs. 170 y ss.; CHOCLÁN MONTALVO, J.A., Deber de cuidado y delito imprudente, Barcelona, 1998, pág. 112, indica, "conforme al principio de confianza, con carácter general no se responde por la falta de cuidado ajeno, sino que el derecho autoriza a confiar en que los otros cumplirán sus deberes de cuidado, respondiendo solamente cuando concurren circunstancias especiales que deben hacer perder la confianza en el cumplimiento del deber ajeno, en cuyo caso el deber de cuidado propio se amplía hasta cubrir el defecto de cuidado de otros"; CALDERÓN, Á./CHOCLÁN MONTALVO, J. A., Derecho Penal, $P G$, t. I, $2^{\mathrm{a}}$ ed., Barcelona, 2001, págs. 344 y s.; en el mismo sentido, HAVA GARCÍA, E., La imprudencia médica, Valencia, 2001, pág., 78; la misma, La imprudencia inconsciente, Granada, 2002, pág. 162; SOTO NIETO, F., "Responsabilidad penal derivada de la actividad médica", VV.AA, Derecho médico. Tratado de Derecho sanitario (MARTÍNEZ CALCERRADA, L./DE LORENZO Y MONTERO, R., dirs.), 2001, pág. 956; BERGMANN, K.-O., "Aufklärung in der arbeitsteiligen Medizin", VV.AA., Risiko Aufklärung. Schmerzensgeld trotz Behandlungserfolg - Wohin führt die Rechtspechung? (RATAJCZAK, T./STEGERS, C. M., coords.), Springer, Berlin/Heidelberg/New York/Hongkong/London/ Meiland/ Paris/ Tokio, pág. 45; SÁNCHEZ CARO, J./ABELLÁN, F., Derechos y deberes de los pacientes. Ley 41/2002 de 14 de noviembre: consentimiento informado, historia clínica, intimidad e instrucciones previas, Granada, 2003, pág. 42.

${ }^{58}$ Sobre la eficacia del principio de confianza, extensión y límites a su aplicación, véase, En la doctrina española, entre otros, ARROYO ZAPATERO, L., La protección penal de la seguridad en el trabajo, Madrid, 1981, pág. 178; el mismo, Manual de Derecho penal del Trabajo, Barcelona, 1988, pág. 88; ZUGALDÍA ESPINAR, J.M., "Algunas observaciones sobre los principios que inspiran la jurisprudencia española en materia de delitos de tráfico", RDCir 1981, págs. 344, y ss.; CORCOY BIDASOLO, M., El Delito, cit., págs. 329 y ss.; JORGE BARREIRO, Ag., La imprudencia, cit., págs. 118 y ss.; LUZÓN PEÑA, D.-M., Curso, cit., pág. 504; CEREZO MIR, J., Curso, cit., págs. 171 y ss.; CHOCLÁN MONTALVO, J.A., Deber, cit., págs. 112 y ss.; FEIJÓO SÁNCHEZ, B., "El principio", cit., págs. 116 y ss.; HAVA GARCÍA, E., La imprudencia médica, cit., págs. 78 y ss.; VILLACAMPA ESTIARTE, C., Responsabilidad, cit., págs. 147 y ss.; GÓMEZ RIVERO, M.C., La responsabilidad, cit., pág. 395; RODRÍGUEZ VÁZQUEZ, V., Responsabilidad, cit., págs. 237 y ss.; BOCKELMANN P./VOLK, K., Strafrecht, cit., pág. 162; CRAMER, P./STERNBERG-LIEBEN, D., VV.AA. StGB, Kommentar (SCHÖNKE/SCHRÖDER, eds.) $27^{\mathrm{a}}$ ed., 2006, § 15-215 y s. 
interesa, el que se refiere a la conducta del que inicialmente aparece amparado por tal principio. Es mayoritaria la doctrina que rechaza la vigencia del principio de confianza para quien infringe con su actuación un deber de cuidado ${ }^{59}$.

Esto significa que la persona que obra imprudentemente no puede esperar que los demás se vayan a comportar diligentemente, en ese caso entra dentro de la previsibilidad del primer sujeto el que el resto de sujetos que realizan esa misma actividad puedan infringir sus respectivos deberes de cuidado y, consecuentemente, puedan concurrir ambas conductas en la producción del resultado lesivo. A partir de aquí, al sujeto se le podrá imputar el resultado finalmente causado, en el que él ha tenido que ver parcialmente, aunque a través de una conducta co-determinante, porque el riesgo total generado y concretado en ese resultado no le era ajeno, sino que debido a su actuación, imprudente, y al contexto en el que se desarrolla, un ámbito de actividad en el que intervienen otros sujetos con actividades también peligrosas, era objetivamente previsible que el resultado lesivo tuviese lugar así, es decir, fuese consecuencia de dos (o más) acciones imprudentes.

Por eso digo que me parece acertada la afirmación de que, en los supuestos de autoría accesoria, sobre todo en ámbitos de actividad como los señalados, que además es donde en buena lógica puede aparecer con mayor facilidad esta forma de autoría, la imputación objetiva del resultado a las acciones que co-determinan el hecho lesivo y, por lo tanto, la imputación recíproca o entre ambas va a ser muy frecuente. Como vemos, en la autoría accesoria se prescinde del acuerdo para fundamentar y justificar la imputación entre los intervinientes, sin que se vea quebrantado el principio de responsabilidad subjetiva. Todo lo contrario, entiendo que sale reforzado.

\section{CRÍTICA, DESDE LA TEORÍA DE LA DETERMINACIÓN OBJETIVA Y POSITIVA DEL HECHO, A LA UTILIZACIÓN DEL ACUERDO COMO REQUISITO NECESARIO PARA LA IMPUTACIÓN RECÍPROCA EN LA COAUTORÍA}

\footnotetext{
59 La aplicación del principio de confianza sólo se realizará a favor de aquel que haya obrado cuidadosamente en su propio ámbito de actuación. Son numerosos los autores que se refieren a este límite del principio de confianza formulándolo, en unos casos, positivamente. Así, WELZEL, H., Das Deutsche Strafrecht. Eine systematische Darstellung, $11^{\mathrm{a}}$ ed., Berlín, 1969, pág. 133; el mismo, Derecho Penal alemán, $P G, 2^{a}$ ed., Santiago de Chile, pág. 159: "el principio de confianza sólo ampara al que se comporta de forma cuidadosa"; en este mismo sentido, FEIJÓO SÁNCHEZ, B., "El principio", cit., pág. 116; JORGE BARREIRO, Ag., La imprudencia, cit., pág. 118: "quien acata las normas, actuando adecuadamente, con normal atención y cuidado, puede tener confianza de que los otros copartícipes han de circular guardando también las disposiciones reglamentarias"; CEREZO MIR, J., Curso, cit., pág. 171: "sólo puede invocar el principio de confianza aquel conductor que observe el cuidado objetivamente debido"; COBO DEL ROSAL, M. (dir.), Comentarios al Código penal, t. I, Madrid, 1999, pág. 553: “el que pone el cuidado preciso puede actuar confiando en que también lo harán los demás". Y en otros casos negativamente, por ejemplo, ZUGALDÍA ESPINAR, J.M., “Algunas observaciones”, cit., pág. 344: "no podrá invocarse el principio de confianza por el que obra descuidadamente"; CORCOY BIDASOLO, M., El Delito, cit., pág. 329: "quien infringe el deber de cuidado exigido por el tráfico, no puede apelar, para sí, al principio de confianza”; CHOCLÁN MONTALVO, J.A., Deber, cit., pág. 116: “el principio de confianza no rige cuando quien lo alega no se ha comportado a su vez correctamente"; VILLACAMPA ESTIARTE, C., Responsabilidad, cit., pág. 147 “quien en su comportamiento no observa el cuidado debido no puede esperar que los demás lo hagan”. Por su parte, ARROYO ZAPATERO, L., Seguridad, cit., pág. 178; el mismo, Derecho, cit., pág. 88, entiende que no se trata de un límite sino del presupuesto de aplicación del principio de confianza.
} 
Desde los postulados de la teoría de la determinación objetiva y positiva del hecho, en mi opinión, es cuestionable que se conceda al acuerdo entidad tal, que sea este el que permita la imputación recíproca y referirse a una acción conjunta (también en la coautoría con imprudencia) ${ }^{60}$. Considero discutible la exigencia de un elemento subjetivo en sede de la autoría y la participación, desde el punto de vista del concepto restrictivo de autor desarrollado de forma estricta que se ha adoptado y que se funda, precisamente, en la exigencia y análisis de elementos exclusivamente objetivos. Tal y como se apuntaba supra, la teoría de la determinación objetiva y positiva del hecho pretende definir quién es autor y quién partícipe atendiendo a la relevancia de la acción en relación con el hecho típico, cuyo análisis y valoración no depende de que el conocimiento o la voluntad del agente abarquen o no las circunstancias que convierten a esa acción en decisiva para la producción del hecho típico, sino de que la acción, valorada en sí misma y atendiendo a las circunstancias concretas del caso, sea suficiente para la producción del resultado ${ }^{61}$. De ahí, además, que la teoría asuma en su denominación la palabra "determinación" y no "dominio" 62 . Por lo tanto, en mi opinión, es problemático que el acuerdo sea el catalizador que permita aplicar el principio de imputación recíproca en los supuestos de coautoría con imprudencia $\mathrm{y}$, de esta forma, exigir a los intervinientes responsabilidad por el resultado lesivo cometido a título de (co)autores ${ }^{63}$.

\footnotetext{
${ }^{60}$ Cuestionándose el principio de imputación recíproca, cfr. BOLEA BARDÓN, C., La cooperación, cit., págs. 33, 49 .

${ }^{61}$ Así, DÍAZ Y GARCÍA CONLLEDO, M., La autoría, cit., pág. 577, puntualiza que “(...) dado que considero que ni siquiera el dolo o la consciencia son elementos propios del dominio del hecho, es decir, fundamentadores específicamente de la autoría, mucho menos correcto me parece exigir otros elementos subjetivos [scil. ánimo o voluntad de autor o interés especial, que eran usados por los planteamientos subjetivos de la autoría], especialmente porque éstos, ni por sí solos, ni combinados con otros objetivos, tienen relación alguna con la realización del tipo". Por lo tanto, no se requiere el conocimiento de la situación de dominio, la finalidad o el dolo por parte del sujeto que realiza una acción que decide la producción del resultado delictivo. Al respecto, véase LUZÓN PEÑA, D.-M., "Alcance", cit., págs. 893 y s.; el mismo, Lecciones, cit., § 18/50; DİAZ Y GARCÍA CONLLEDO, M., La autoría, cit., págs. 628, 691; el mismo, "La autoría en Derecho penal", cit., pág. 46; LUZÓN PEÑA, D.-M./DÍAZ Y GARCÍA CONLLEDO, M., "Determinación", cit., pág. 67; los mismos, "Objektive positive Tatbestimmung", cit., pág. 589; los mismos, "Determinación objetiva", cit., págs. 104 y s.

${ }_{62}$ Cfr. LUZÓN PEÑA, D.-M., "Alcance”, cit., págs. 893 y s.; el mismo, Lecciones, cit., § 18/50; DÍAZ Y GARCÍA CONLLEDO, M., La autoría, cit., págs. 1991, 628, 691; el mismo, "La autoría en Derecho penal", cit., pág. 46; el mismo, "Un diálogo", cit., pág. 15; LUZÓN PEÑA, D.-M./DÍAZ Y GARCÍA CONLLEDO, M., "Determinación", cit., pág. 67; los mismos, "Objektive positive Tatbestimmung", cit., pág. 589; los mismos, "Determinación objetiva", cit., págs. 104 y s.

${ }^{63}$ Cfr. GARCÍA DEL BLANCO, M.V., La coautoría, cit., pág. 432 quien realiza, si interpreto correctamente sus palabras, una reflexión en el mismo sentido: "Tratar de salvar las dificultades que presenta el sometimiento obligado al principio de autonomía de la responsabilidad individual del coautor y la responsabilidad por el hecho global realizado conjuntamente por los coautores acudiendo únicamente al requisito del mutuo acuerdo como elemento subjetivo implicaría asumir que la responsabilidad por lo no realizado personalmente deriva únicamente de un factor subjetivo común y acercarnos efectivamente a los postulados mantenidos por las teorías subjetivas - al menos en lo relativo al incremento de pena que generalmente se produciría con la aplicación del Derecho positivo vigente para la actuación del coautor con relación a la pena que derivaría de su intervención individualmente considerada-. Personalmente rechazo la necesidad del mutuo acuerdo para considerar al sujeto autor del hecho realizado conjuntamente, afirmando, aunque pueda parecer contradictorio, que responderá del hecho en virtud del principio de responsabilidad personal de su propia conducta. La valoración jurídica que debe hacerse de dicha conducta propia dependerá del entorno en que se inserte. El que no se pueda hacer responsable penalmente a un sujeto por acciones ajenas en ningún caso significa que dichas conductas ajenas no deban ser tenidas en cuenta para poder determinar el significado normativo de la acción propia”.
} 
Esta duda se funda, además, en la comparación de la coautoría con la autoría accesoria y las soluciones penales a las que se llega en cada una de ellas. En este sentido, comparto la posición adoptada por GARCÍA DEL BLANCO, quien considera que el uso del acuerdo, como reflejo de la imputación recíproca de un hecho, para fundamentar la coautoría, es una manifestación de la exigencia de responsabilidad por hecho ajeno, insostenible en Derecho penal, al regir el principio de responsabilidad personal $^{64}$. En la coautoría, al igual que en la autoría accesoria o en cualquier forma de autoría, el sujeto debe responder por hechos propios.

La imputación objetiva es el instrumento que permite atribuir responsabilidad penal a cada uno de los intervinientes que realizan aportaciones propias de autor en la realización de un hecho. Así, "cada autor responde penalmente por su propia conducta, sin embargo, la responsabilidad penal derivada de dicha conducta en ningún caso está limitada al ámbito de ejecución material llevada a cabo por el sujeto. Habrá que valorarla tanto objetiva como subjetivamente. Dicho juicio normativo dependerá en gran medida del contexto en el que se enmarque la intervención individual. En este sentido, conocer o haber debido conocer que la conducta propia incrementa un riesgo incluso previamente creado - por ejemplo, en caso de coautoría sucesiva- por un tercero autorresponsable a su vez, debe tenerse en cuenta dentro del marco de análisis de la imputación objetiva del riesgo o del resultado producido. Del mismo modo se tendrán en cuenta conductas futuras o coetáneas que interfieran en el curso causal de la propia conducta incrementando el peligro creado por ésta, siempre y cuando fueran objetivamente previsibles. Y una vez determinado el tipo objetivo en el que se inscribe dicha conducta, habrá que determinar si el mismo está abarcado por dolo o por imprudencia" 65 . De esta forma, "el punto de partida son los conocimientos individuales que tenga o haya debido tener el sujeto en concreto, porque constituyen la parte de la realidad en la que se desarrolla su comportamiento. Así, el juicio de previsibilidad objetiva deberá mantenerse dentro de la realidad conocida o que debiera haber sido conocida por el sujeto. (...) Cuando en un hecho intervienen una pluralidad de sujetos, ese hecho consistente en la intervención plurisubjetiva en la dinámica comisiva, forma parte de la realidad objetiva en la que se inserta la conducta de cada uno de ellos. Por ello, se deberá valorar el peligro objetivo que comporta la intervención de cada sujeto en una realización conjunta del hecho, teniendo en cuenta si el sujeto en concreto conocía o debía haber conocido ese dato objetivo. Para la correcta valoración del peligro objetivamente previsible ex ante que representa una conducta no se puede tener en cuenta únicamente la aportación individual del sujeto desde una perspectiva abstracta, haciendo abstracción de la realidad o del contexto en el que se ha realizado concretamente. Por el contrario, una correcta valoración de la conducta debe tener en cuenta la aportación dentro del contexto determinado en el que se produce, en el marco de una confluencia de conductas realizadas por otros sujetos de una determinada forma. Así, las aportaciones del resto de los coautores formarían el contexto objetivo de peligro en concreto en el que realiza la aportación y que influirán decisivamente en el peligro que se atribuya a dicha aportación"

\footnotetext{
${ }^{64}$ Cfr. GARCÍA DEL BLANCO, M.V., La coautoría, cit., págs. 432 y s. Cfr., también, la recensión de SÁNCHEZ LÁZARO, F.G., "El ocaso de la resolución conjunta. Recensión a Victoria García del Blanco, La coautoría en Derecho penal, Tirant lo Blanch, Valencia, 2006, 734 p.”, InDret 2/2007, págs. 1-10.

${ }^{65}$ GARCÍA DEL BLANCO, M.V., La coautoría, cit., pág. 433.

${ }^{66}$ GARCÍA DEL BLANCO, M.V., La coautoría, cit., págs. 654, 691, 693.
} 
Por lo tanto, se llega a una solución muy próxima a la aquí propuesta y con la que estoy de acuerdo. No obstante, esta autora va más allá y declara la innecesaridad absoluta del acuerdo como elemento constitutivo de la coautoría, pues no refleja, a su modo de ver, un incremento del riesgo ni una justificación de un incremento de la responsabilidad penal para los sujetos que así actúan ${ }^{67}$. Se diluye de esta forma definitivamente la distinción entre coautoría y autoría accesoria ${ }^{68}$. Con esta última postura ya no puedo estar de acuerdo, por las razones y con las precisiones que se exponen a continuación.

\section{UNA PROPUESTA DE REINTERPRETACIÓN DEL PAPEL DEL ACUERDO Y DE SU UBICACIÓN SISTEMÁTICA EN LA COAUTORÍA CON IMPRUDENCIA}

En este epígrafe, partiendo de la teoría de la determinación objetiva y positiva del hecho, defenderé la idea según la cual en el ámbito del tipo positivo objetivo ${ }^{69}$, solo se deben tener en cuenta criterios objetivos para calificar la conducta de un sujeto como de autor o de partícipe. Razón por la cual, el análisis del elemento subjetivo "acuerdo" y su contenido tendrán que ser analizados en la categoría dogmática que les corresponde, en el tipo positivo subjetivo. Conforme a esta idea, entonces, afirmo que:

1. En el tipo positivo objetivo y, en concreto, en sede del análisis de la autoría y participación, según la teoría de la determinación objetiva y positiva, para afirmar que existe coautoría se debe comprobar que ha existido "co-determinación" del hecho, haciendo una verificación de los tres subrequisitos que supra se indicaban: a) que concurran, al menos, dos acciones o más en la producción del hecho delictivo; b) que cada una de las acciones sea insuficiente para producir el hecho por sí sola; y c) que la

\footnotetext{
${ }^{67}$ Cfr. GARCÍA DEL BLANCO, M.V., La coautoría, cit., págs. 646, 656 y ss., 688 y s.

${ }^{68}$ Cfr. GARCÍA DEL BLANCO, M.V., La coautoría, cit., pág. 695.

69 En este trabajo asumo la teoría de los elementos negativos del tipo. Siguiendo a LUZÓN PEÑA, entiendo que el dolo requiere conocimiento (y voluntad) de realizar todos los elementos objetivos del tipo total de injusto, es decir, tanto los elementos objetivos positivos del tipo de injusto (del tipo indiciario o estricto) como los elementos negativos del tipo, es decir, la ausencia de los presupuestos objetivos o materiales de las causas de atipicidad y de justificación. Solo la concurrencia en la conducta de todos estos elementos o circunstancias contenidas en el tipo penal (explícita e implícitamente) hace que se realice realmente un hecho típicamente antijurídico. Véase, al respecto, LUZÓN PEÑA, D.-M., Aspectos esenciales de la legítima defensa, Barcelona, 1978, pág. 251, n. 253; el mismo, "El error sobre las causas de justificación: algunas precisiones (Comentario a la STS 10-5-1989)", Estudios Penales, Barcelona, 1991, págs. 72 y ss.; el mismo, "Concurrencia aparente o real de error sobre presupuestos o sobre límites de una causa de justificación (Error sobre la ilegalidad de una detención intimidatoria de autoridad por funcionario)", Estudios Penales, Barcelona, 1991, págs. 97 y ss.; el mismo, "La relación del merecimiento y de la necesidad de pena con la estructura del delito", $A D P C P$ 1993, pág. 30, n. 41; el mismo, "Error sobre causas de justificación", EJB II, 1995, págs. 2845 y ss.; el mismo, "Tipo (penal)", EJB IV, 1995, págs. 6543 y s.; el mismo, "Error sobre causas de justificación”, EPB, 2002, pág. 666; el mismo, “Tipo (penal)”, EPB, 2002, pág.1171; el mismo, Lecciones, cit., § 12/10, 16/32, 17/75. También siguen esta teoría, entre muchos otros, DÍAZ Y GARCÍA CONLLEDO, M., "Inducción o autoría mediata en malversación impropia", $L L$ 1986-4, pág. 525; el mismo, "Los elementos normativos del tipo penal y la teoría del error", Em-Casabó I, 1997, págs. 674 y s.; el mismo, "El error de prohibición: pasado, presente y futuro", LH-Torio, 1999, pág. 349; el mismo, “¿Error de tipo o error de hecho?”, Em-Valle, 2001, pág. 224; el mismo, El error sobre elementos normativos del tipo penal, Madrid, 2008, págs. 108, 172; OLAIZOLA NOGALES, I., El error de prohibición. Especial atención a los criterios para su apreciación y para la determinación de su vencibilidad e invencibilidad, Madrid, 2007, pág. 38, n. 17. Para un detallado análisis de las críticas y respuestas a dichas críticas que se le hace a la teoría de los elementos negativos del tipo, en el contexto de la teoría de la culpabilidad, véase TRAPERO BARREALES, M.A., El error en las causas de justificación, Valencia, 2004, págs. 223 y ss.
} 
conjunción de las acciones realizadas por distintas personas, y sólo esa conjunción, sea la que co-determine objetiva y positivamente el hecho.

2. La existencia o no de acuerdo entre los intervinientes en una o varias conductas imprudentes que converjan es relevante para apreciar las diferencias de desvalor de la conducta entre los sujetos, y su verificación y análisis deben hacerse en el tipo positivo subjetivo, por lo que propongo una reubicación sistemática del acuerdo en el lugar que le corresponde según la teoría del delito.

Ante esta solución se podría pensar que se aboga por una unificación de las consecuencias de la coautoría y de la autoría accesoria ${ }^{70}$. No es así, como ya apuntaba. Es cierto que, según mi propuesta tanto en los tradicionalmente llamados "casos de coautoría" como en los llamados "casos de autoría accesoria", se va a poder calificar en el plano objetivo a los intervinientes como "autores", de hecho, estrictamente, en la mayoría de los casos, como "coautores" del resultado lesivo causado. Ahora bien, considero que la forma de intervención (y en concreto, si ha existido acuerdo o no) en el tipo positivo subjetivo va a influir en la gravedad del hecho, en definitiva, en el grado de injusto y, por tanto, en la determinación de la pena. En este sentido, considero que por regla general, tanto en conductas dolosas pero también imprudentes, la actuación conjunta y acordada de varios sujetos (coautoría), revela un mayor desvalor de acción, por tanto, un mayor merecimiento de pena, que la actuación de una pluralidad de sujetos pero sin acuerdo (autoría accesoria). El elemento clave en este sentido seguirá siendo el "acuerdo", como hasta ahora, pero en tanto elemento subjetivo deberá ser analizado en donde le corresponde sistemáticamente en la teoría del delito.

Por lo tanto, soy consciente de que en el tipo objetivo, en el análisis que le corresponde a la autoría y la participación, se desdibujaría la clásica distinción entre coautoría con imprudencia y autoría accesoria con imprudencia. Pero, en mi opinión, no hay que alarmarse excesivamente, puesto que, en dicho plano, no dejaríamos de estar hablando de "realización conjunta del hecho", de "co-determinación del hecho", que es el elemento que define la coautoría, según la literalidad del CP y la doctrina ${ }^{71}$. También, como se mencionaba supra, en el epígrafe III, se podrá imputar objetivamente el resultado a la conducta de los intervinientes en los clásicos ejemplos de la llamada autoría accesoria, por lo que estos casos no quedarían tampoco desatendidos, según la interpretación que propongo.

Por todo lo dicho, estos grupos de casos (tanto en los tradicionalmente llamados "casos de coautoría" como en los llamados "casos de autoría accesoria") no

\footnotetext{
70 Tal y como se explicaba supra, no hay diferencias en el elemento subjetivo sino en el elemento objetivo.

${ }^{71}$ El art. 28 CP dice: "Son autores quienes realizan el hecho por sí solos, conjuntamente o por medio de otro del que sirven como instrumento". Véase, además, DÍAZ Y GARCÍA CONLLEDO, M., La autoría, cit., págs. 651 y ss.; el mismo, "Dominio funcional", cit., págs. 305-307; el mismo, "Autoría mediata, coautoría", cit., págs. 702 y ss.; el mismo, "Autoría", cit., pág. 147; el mismo, "Autoría mediata”, cit., págs. 173 y ss.; el mismo, "La autoría en Derecho penal”, cit., págs. 54 y ss.; el mismo, "Autoría y participación” (2008), cit., págs. 30 y ss.; el mismo, "La influencia”, cit., págs. 37 y ss.; el mismo, "Claus Roxin y la llamada autoría”, cit., págs. 376 y s.; GONZÁLEZ RUS, J.J., “Autoría”, cit., págs. 57 y ss.; DE LA MATA BARRANCO, N.J., "La participación “, cit., págs. 99 y ss.; PÉREZ ALONSO, E.J., La coautoría, cit., passim; SOTO NIETO, F., "Coautoría”, cit., págs. 1774 y ss.; DURÁN SECO, I., La coautoría, cit., passim; SÁNCHEZ LÁZARO, F.G., Intervención, cit., pág. passim; TRILLO NAVARRO, J.P., "Imprudencia”, cit., págs. 18 y ss.; RODRÍGUEZ VÁZQUEZ, V., Responsabilidad, cit., págs. 383 y ss.; CADAVID QUINTERO, A., Imprudencia, cit., págs. 353 y ss.
} 
tienen por qué perder, desde un punto de vista global de la teoría del delito, su singularidad; mi propuesta pasa simplemente por intentar concretar sus elementos de forma coherente con la teoría de la determinación positiva y objetiva del hecho y, así, conseguir una mayor precisión dogmática en el análisis de intervenciones plurales imprudentes. Por lo tanto, en los casos en los intervengan dos o más sujetos que cometan sucesivas imprudencias en la realización de una conducta peligrosa, la posibilidad de imputarles el carácter de coautores, de autores accesorios, o de partícipes imprudentes, dependerá de cuáles de las acciones concurrentes puedan considerarse determinantes para configurar la afectación del bien jurídico, según sus posibilidades de definir el si y el cómo del hecho ${ }^{72}$.

En mi opinión, según la propuesta que realizo en este trabajo se podría distinguir entre los siguientes grupos de casos:

1. Casos de coautoría con acuerdo o imprudencia conjunta, que serían aquellos casos en los que, en el tipo objetivo, existe una co-determinación del hecho y es posible imputarle objetivamente el resultado causado a cada uno de los intervinientes; y que en el tipo subjetivo, existió un acuerdo, un proyecto común en la ejecución de la conducta descuidada o peligrosa. Aquí encajarían todos los casos en los que se admite tradicionalmente la coautoría con imprudencia.

2. Casos de coautoría con imprudencia accesoria o sin acuerdo, que serían aquellos casos en los que, en el tipo objetivo, existe una co-determinación del hecho y es posible imputarle objetivamente el resultado a la conducta de cada uno de los intervinientes; pero que, en el tipo subjetivo no existió acuerdo en la ejecución de la conducta descuidada o peligrosa. En este grupo encajaría el ejemplo del conductor de un coche que al llegar a un cruce no respeta la señal de "stop" y se introduce sin detenerse en la vía preferente, y otro automovilista que llega por esta vía preferente lo hace desatento y a gran velocidad, sin respetar el límite de velocidad que había al acercarse al cruce, por lo que chocan ambos vehículos. En este caso, insisto, habría codeterminación del hecho, y se podrá imputar objetivamente el resultado a cada uno de los conductores "por ser adecuada esa forma (curso causal) de producirse el resultado, y por suponer éste, aunque su causación haya sido en conjunción con otra conducta, la realización de un riesgo inherente a aquella conducta imprudente y que la norma pretendía evitar"73. Finalmente, en el tipo subjetivo no habría acuerdo.

3. Casos de autoría accesoria imprudente, que serían aquellos casos en los que, en el tipo objetivo, aun existiendo una co-determinación del hecho, no existe posibilidad de imputar objetivamente el resultado a la conducta de cada uno de los intervinientes; $y$, además, en el tipo subjetivo no existió acuerdo en la ejecución de la conducta descuidada o peligrosa.

Así pues, desde mi punto de vista, el acuerdo es un elemento necesario para distinguir el grado de desvalor existente entre una conducta en la que medie acuerdo y otra en la que no exista tal. Necesario, en cuanto permite diferenciar la coautoría con imprudencia conjunta de la llamada coautoría con imprudencia accesoria, siempre

\footnotetext{
${ }^{72}$ Cfr. CADAVID QUINTERO, A., Imprudencia, cit., pág. 342.

${ }^{73}$ LUZÓN PEÑA, D.-M., “Alcance”, cit., pág. 899; el mismo, Curso, cit., pág. 510; LUZÓN PEÑA, D.M./DÍAZ Y GARCÍA CONLLEDO, M., "Determinación”, cit., pág. 85; los mismos, “Objektive positive Tatbestimmung”, cit., pág. 606; los mismos, “Determinación objetiva”, cit., págs. 124 y s.
} 
teniendo por base, y es lo que intento dejar claro en la denominación que propongo, se cumpla con la exigencia de que las aportaciones de cada uno de los sujetos intervinientes sean objetivamente (co)determinantes, en el sentido que ya hemos definido, del hecho. Por otra parte, he tratado de demostrar que la imputación "recíproca" o "conjunta" se puede y se debe constatar a través de la imputación objetiva tanto en los supuestos de coautoría con imprudencia conjunta como de coautoría con imprudencia accesoria. Por lo tanto, el acuerdo en el tipo subjetivo es el elemento que nos permite definir a la coautoría con imprudencia conjunta y distinguirla de la coautoría con imprudencia accesoria, en cuanto supone un mayor desvalor de injusto y, consecuentemente, una mayor pena. Esta idea es congruente con el sector doctrinal que ha advertido de la necesidad de disminuir las consecuencias penales que corresponde atribuir a los intervinientes en supuestos de "autoría accesoria imprudente" frente a los casos de "coautoría imprudente" ".

Esta idea ha sido esbozada anteriormente por LUZÓN PEÑA ${ }^{75}$ y la apunta DÍAZ Y GARCÍA CONLLEDO al afirmar que "la coautoría en los delitos imprudentes, que aparece cuando mediante un 'acuerdo', los sujetos se reparten la realización de la acción imprudente determinante (así, por ejemplo, LUZÓN PEÑA, ADPCP 1989, 898 s.), plantea diversos problemas, que aquí no puedo tratar, entre otros el de si tiene alguna trascendencia penal su distinción respecto de la actuación parcial determinante de varios sin acuerdo, o sea de la autoría accesoria imprudente (o concurrencia de culpas, siempre que las "culpas" concurrentes se refieran a acciones determinantes junto a las otras y no sólo favorecedoras de las otras): probablemente, al contrario que en la autoría accesoria dolosa, no servirá para impedir que se responda por el resultado consumado (lo que, naturalmente, de producirse, daría lugar a la impunidad en los delitos imprudentes, pues en ellos no se castiga la tentativa), pero quizá sí tenga importancia o influencia en la determinación del grado de imprudencia con que actuó cada sujeto. (...) con lo que, en algunos casos, la influencia fundamental de la concurrencia de conductas imprudentes (de autoría accesoria) será sobre el grado de imprudencia de cada conducta" 76 .

En mi opinión, la coautoría con imprudencia conjunta o acuerdo revela un mayor desvalor respecto a la coautoría con imprudencia accesoria por varias razones. En primer lugar, es cierto que "una equivalencia entre el acuerdo común en los delitos dolosos y los delitos imprudentes es imposible de realizar, ya que el acuerdo común en los delitos dolosos persigue la realización típica de un fin común, basado en la división del trabajo, lo que conduce a un mejoramiento de las posibilidades de realización del delito que se traduce en el mundo exterior en la elevación del riesgo"77, sin embargo creo que este mismo razonamiento es aplicable mutatis mutandi a los supuestos de coautoría con imprudencia conjunta. En este sentido se pueden traer a colación las palabras de GUTIÉRREZ RODRÍGUEZ, “consideramos que también en los supuestos de correalización de una actuación imprudente existe un incremento de riesgo en la lesión del bien jurídico, pues al igual que en el dolo se puede proceder bien a una división del trabajo o, lo que será más frecuente en la imprudencia, a una acumulación

\footnotetext{
${ }^{74}$ ROSO CAÑADILLAS, R., Autoría, cit., pág. 593; también LUZÓN PEÑA, D.-M., Curso, cit., pág. 510; PAREDES CASTAÑÓN, J.M., en PAREDES CASTAÑÓN, J.M./RODRÍGUEZ MONTAÑÉS, T., El caso, cit., pág. 147.

${ }^{75}$ Véase LUZÓN PEÑA, D.-M., “Alcance”, cit., pág. 899; el mismo, Curso, cit., pág. 510.

${ }^{76}$ DÍAZ Y GARCÍA CONLLEDO, M., La autoría, cit., págs. 635 y s.

${ }^{77}$ ROSO CAÑADILLAS, R., Autoría, cit., pág. 583.
} 
de esfuerzos que sin duda facilitará la lesión del bien jurídico"78. En segundo lugar y siguiendo a la misma autora, "en supuestos de coautoría el acuerdo puede producir una situación de refuerzo psicológico que aunque no vaya dirigida a la consecución del resultado, puede dar lugar a un proceso de motivación recíproca que haga al sujeto decidirse a realizar la actuación imprudente junto a los demás"79.

En resumen, la distinción entre coautoría con imprudencia conjunta o con acuerdo, coautoría con imprudencia accesoria o sin acuerdo y autoría con imprudencia accesoria tiene consecuencias a la hora de determinar la responsabilidad penal de cada uno de los sujetos.

\section{CONTENIDO DEL ACUERDO EN LA COAUTORÍA CON IMPRUDENCIA CONJUNTA}

La determinación del contenido del acuerdo en la coautoría con imprudencia conjunta no resulta sencilla, entre otras cuestiones, debido al escaso desarrollo doctrinal de esta forma de autoría cuando se trata de intervenciones imprudentes, en contraposición con el mayor estudio de la coautoría dolosa. De manera que la coautoría con imprudencia conjunta siempre ha ido "a remolque" de los planteamientos generados en el ámbito doloso. Tal es así que la doctrina ha utilizado la configuración del contenido del acuerdo en los supuestos de coautoría dolosa para negar la posibilidad de su concurrencia en los casos de intervenciones imprudentes y, consecuentemente, abortar la posibilidad de apreciar la tradicionalmente llamada "coautoría imprudente" Algunos autores han puesto de manifiesto lo equivocado de tal decisión, derivada de identificar acuerdo con "dolo común" "81, lo que suponía exigir que los intervinientes manifestasen, a través del acuerdo, su voluntad de producir el resultado, algo inadmisible por definición en la imprudencia.

Ahora bien, el contenido del acuerdo es diferente en la coautoría con imprudencia conjunta, es decir, tiene un alcance distinto al que posee en la coautoría dolosa. La diferencia fundamental estriba en que el acuerdo en la coautoría con imprudencia conjunta no puede abarcar el resultado que, por definición, queda al margen del propio comportamiento imprudente. El acuerdo se debe limitar a la acción descuidada, es decir, a la acción que a causa de impericia o descuido de los intervinientes infringe el cuidado debido generando un riesgo no permitido que se concreta en el resultado final ${ }^{82}$. La exigencia de que el acuerdo vaya referido a la acción descuidada determina de forma precisa su contenido. Necesariamente, los intervinientes deben conocer la aportación al hecho del otro sujeto, de manera que teniendo la posibilidad de percibir que la conjunción de ambas conductas, de esa concreta forma y

\footnotetext{
${ }^{78}$ GUTIÉRREZ RODRÍGUEZ, M., La responsabilidad, cit., págs. 261 y s.

${ }^{79}$ GUTIÉRREZ RODRÍGUEZ, M., La responsabilidad, cit., págs. 261 y s.

${ }^{80}$ Véase LUZÓN PEÑA, D.-M., "Alcance", cit., págs. 898 y s.; LUZÓN PEÑA, D.-M./DÍAZ Y GARCÍA CONLLEDO, M., "Determinación", cit., págs. 83 y ss.; los mismos, "Objektive positive Tatbestimmung", cit., pág. 605; los mismos, "Determinación objetiva", cit., pág. 123; GUTIÉRREZ RODRÍGUEZ, M., La responsabilidad, cit., págs. 207 y ss. ROSO CAÑADILLAS, R., Autoría, cit., pág. 562; MIR PUIG, S., $P G$, cit., pág. 409.

${ }^{81}$ GUTIÉRREZ RODRÍGUEZ, M., La responsabilidad, cit., pág. 210; ROSO CAÑADILLAS, R., Autoría, cit., pág. 581; BOLEA BARDÓN, C., La cooperación, cit., pág. 38.

${ }^{82}$ LUZÓN PEÑA, D.-M., "Alcance", cit., págs. 898 y s.; siguiendo a su maestro, DÍAZ Y GARCÍA CONLLEDO, M., La autoría, cit., pág. 655; GUTIÉRREZ RODRÍGUEZ, M., La responsabilidad, cit., págs. 214 y s.; ROSO CAÑADILLAS, R., Autoría, cit., pág. 581 y s.
} 
en ese determinado instante, rebasaría el riesgo permitido, creando un peligro determinante del resultado, no lo hacen, o confían infundadamente en que no se llegue a producir el resultado.

Esta mayor precisión sobre el objeto del acuerdo, contrasta con la configuración, en mi opinión más vaga, de su contenido en la coautoría dolosa. La mayoría de la doctrina entiende el acuerdo, en relación con la coautoría dolosa, en un sentido amplio, lo que se traduce en que para comprobar su existencia no se exige que cada uno de los intervinientes conozca con exactitud la concreta aportación de los demás, sino que en muchos casos se dice que es suficiente con saber que se actúa conjuntamente con otros en la realización del hecho, sin que sea necesario conocer a las personas con las que se interactúa ${ }^{83}$.

En mi opinión, para afirmar el acuerdo en la coautoría con imprudencia conjunta no es suficiente con que el sujeto sea consciente de que actúa con otros, o de que junto a él participan otras personas, o que tenga un conocimiento general y no preciso de la intervención de los demás, o que no sea necesario que conozca todos los detalles de la realización conjunta. Estos criterios pueden ser válidos para establecer el contenido del acuerdo en la coautoría dolosa, en donde lo fundamental es la voluntad de realizar el hecho delictivo, es decir, de producir el resultado, de manera que parece que puede ser suficiente para afirmar la existencia de un acuerdo penalmente relevante que los sujetos que comparten esa voluntad tengan un conocimiento recíproco de la existencia de otros sujetos que comparten el mismo fin y que van a realizar alguna actuación complementaria para conseguirlo. Por eso, en estos casos se puede ser menos exigente, menos restrictivo a la hora de establecer el alcance del acuerdo, dando cabida así a conductas que, de otra forma, quedarían excluidas del ámbito de la coautoría ${ }^{84}$.

Ahora bien, decir que basta con que el sujeto sepa que interactúa con otros para afirmar el acuerdo sería tanto como decir que en los supuestos de división del trabajo en la realización de cualquier actividad, la concurrencia de dos conductas imprudentes que determinan el resultado lesivo (es decir, que cumplen con el requisito objetivo de la coautoría con imprudencia conjunta, pero, recordemos, también de la coautoría con imprudencia accesoria), constituyen siempre casos de coautoría con imprudencia conjunta, algo que, bajo mi punto de vista, es incorrecto. Esto es así porque, no existiendo una finalidad lesiva en los actores, el hecho de que organicen su actividad en régimen de división del trabajo y que, por lo tanto, sepan que intervienen con otros sujetos e, incluso, puedan saber lo que los otros realizan o van a realizar, no nos dice todavía nada sobre lo realmente importante en la coautoría con imprudencia conjunta, la acción conjunta co-determinante y acordada.

En el ámbito de la imprudencia, el acuerdo, cuya materialización o concreción no está exenta de dificultades, es relevante en relación con la coautoría con imprudencia

\footnotetext{
${ }^{83}$ Véase GUTIÉRREZ RODRÍGUEZ, M., La responsabilidad, cit., págs. 133, 135 y s.; DURÁN SECO, I., La coautoría, cit., págs. 407, 408 y s.; GARCÍA DEL BLANCO, M.V., La coautoría, cit., pág. 489.

${ }^{84}$ DURÁN SECO, I., La coautoría, cit., pág. 409, señala que "de este modo, no se cierra el paso a la coautoría en la denominada coautoría sucesiva, ni tampoco en los supuestos de aparatos organizados de poder en los que por las estructuras que caracterizan estos supuestos los sujetos no se conocen entre sí (pero saben que otros actúan "al lado", "arriba" o "debajo")"; en el mismo sentido, GARCÍA DEL BLANCO, M.V., La coautoría, cit., pág. 489, considera que "de exigirse un conocimiento detallado y preciso en el momento de comienzo de ejecución de la actuación futura de cada una de las intervenciones individuales se cerraría prácticamente la puerta a la apreciación de la coautoría".
} 
conjunta porque supone un "plus" de antijuridicidad, no respecto a la autoría individual sino respecto a la coautoría con imprudencia accesoria, según lo que hemos dicho anteriormente. Por esa razón decíamos que en la coautoría con imprudencia conjunta los sujetos responderán como autores individuales, sin que se pueda establecer una "compensación de culpas", frente a la coautoría con imprudencia accesoria o sin acuerdo, en la que sí se puede dar una atenuación de la pena que corresponde a cada uno de los intervinientes. Eso sí, para que al acuerdo se le pueda atribuir esa consecuencia (ser un "plus" respecto a la coautoría con imprudencia accesoria o sin acuerdo), es necesario que vaya referido a la concreta acción resultante de la intervención conjunta.

Por lo tanto, el acuerdo en la coautoría con imprudencia conjunta debe ser entendido en un sentido más estricto que en la coautoría dolosa. Estos sujetos deben decidir de mutuo acuerdo ("poniéndose de acuerdo") la realización de una concreta actuación en un determinado momento, lo cual implica que en ese concreto supuesto ninguno deba seguir las órdenes o instrucciones de otro, puesto que en ese caso, normativamente ya no hablaríamos de un acuerdo, que implica reciprocidad, aunque, de hecho, la persona que tenga que seguir una orden pueda estar de acuerdo con el contenido de la misma ${ }^{85}$. Con lo que cada uno de ellos sabe cuál es la aportación del otro y debe conocer las consecuencias de esa concreta intervención conjunta. Por otra parte, de lo apuntado líneas atrás se puede deducir que los supuestos de coautoría con imprudencia conjunta podrán darse, atendiendo a su elemento subjetivo, con una mayor facilidad en los casos de división horizontal del trabajo, pues el mutuo acuerdo referido a una concreta acción ha de suponer, generalmente, que los profesionales se encuentren en una posición de igualdad, es decir, compartan el mismo poder de decisión respecto a esa concreta acción conjunta.

\section{CONCLUSIONES}

1. Son muchas las teorías que a lo largo de la historia del Derecho penal se han desarrollado para explicar el concepto de autor. De entre las distintas teorías desarrolladas la que se defiende en este trabajo es la "teoría de la determinación objetiva y positiva del hecho", creada por LUZÓN PEÑA, desarrollada por DÍAZ Y GARCÍA CONLLEDO y estudiada en profundidad por, entre otros, una amplia Escuela.

2. Los motivos para adoptar y defender esta teoría son fundamentalmente de corte dogmático, aunque también políticocriminal. Se considera que esta teoría profundiza en el concepto restrictivo de autor, respondiendo con máxima coherencia a los principios limitadores del ius puniendi propios de un Estado de Derecho. En particular a los principios de legalidad, derivado de éste, taxatividad, de intervención mínima y de ultima ratio.

3. La teoría de la determinación objetiva y positiva del hecho se ha caracterizado desde sus orígenes por prescindir de cualquier elemento subjetivo para explicar la autoría en cualquiera de sus manifestaciones: unipersonal, mediata, coautoría y autoría accesoria. Esto ha permitido desarrollar una teoría aplicable tanto a delitos

\footnotetext{
${ }^{85}$ En este mismo sentido, BOLEA BARDÓN, C., La cooperación, cit., pág. 32, señala que "ello [codominio] implica compartir el dominio desde una posición de igualdad, jurídicamente reconocida como tal, aunque fácticamente no sea completa. En efecto, el dominio del riesgo en la coautoría se ejerce en un plano de igualdad, y no desde distintas posiciones, como sucede con la figura del autor tras el autor, pues la coautoría manifiesta una estructura horizontal, y no vertical".
} 
dolosos como imprudentes, lo que constituye uno de sus grandes aportes a la teoría del delito.

4. Esa línea de objetividad se desvía, sin embargo, en relación con la coautoría cuando se considera que el acuerdo entre los intervienes es el título de imputación recíproca requerido para poder atribuir en concepto de (co)autores un mismo hecho a dos o más sujetos (cumpliéndose los demás elementos de la teoría del delito y el requisito de la co-determinación positiva del hecho exigido por esta teoría para afirmar la autoría). Sin embargo, en los supuestos llamados de autoría accesoria, estructuralmente idénticos a los de autoría pero sin concurrencia de acuerdo entre los intervinientes es posible, tradicionalmente desde esta teoría, atribuir responsabilidad a los sujetos intervinientes comprobando la imputación recíproca del hecho a cada uno de los intervinientes a través de la imputación objetiva (cumpliéndose nuevamente aquí los demás elementos de la teoría del delito y el requisito de co-determinación positiva del hecho exigido por esta teoría para afirmar la teoría).

5. En mi opinión, el acuerdo no debe ser entendido como título de imputación recíproca necesario para poder afirmar la coautoría. Abogo por considerar que la argumentación utilizada desde la teoría de la determinación objetiva y positiva para imputar recíprocamente un hecho a dos o más sujetos en los supuestos de autoría accesoria acudiendo a la imputación objetiva, sea transpolable a los supuestos de coautoría, tanto dolosa pero sobre todo, y donde tiene especial importancia, imprudente. En consecuencia, el acuerdo no juega un papel en orden a atribuir la responsabilidad a los sujetos intervinientes en calidad de (co)autores.

6. Eso, sin embargo, no significa que no juegue ningún papel. En mi opinión, en el ámbito del tipo positivo objetivo, solo se deben tener en cuenta criterios objetivos para calificar la conducta de un sujeto como de autor o de partícipe. Razón por la cual, el análisis del elemento subjetivo "acuerdo" y su contenido tendrán que ser analizados en la categoría dogmática que le corresponde, en el tipo positivo subjetivo. Así, el acuerdo sí diferencia la coautoría de la autoría accesoria, pero a efectos de la valoración del grado de injusto y, por tanto, de determinación de la pena. En este sentido, considero que por regla general, tanto en conductas dolosas pero también imprudentes, la actuación conjunta y acordada de varios sujetos (coautoría), revela un mayor desvalor de acción, por tanto, un mayor merecimiento de pena, que la actuación de una pluralidad de sujetos pero sin acuerdo (autoría accesoria).

7. Según esta propuesta, en el tipo positivo objetivo, en el análisis que le corresponde a la autoría y la participación, se desdibujaría la clásica distinción entre coautoría con imprudencia y autoría accesoria con imprudencia. Pero no dejaríamos de estar hablando de "realización conjunta del hecho", de "co-determinación del hecho", que es el elemento que define la coautoría, según la literalidad del $\mathrm{CP}$. Además, se cuenta con la imputación objetiva para poder imputar recíprocamente el hecho.

8. Según la propuesta que realizo en este trabajo se podría distinguir entre los siguientes grupos de casos: a) casos de coautoría con acuerdo o imprudencia conjunta, que serían aquellos casos en los que, en el tipo objetivo, existe una co-determinación del hecho y es posible imputarle objetivamente el resultado causado a cada uno de los intervinientes; y que en el tipo subjetivo, existió un acuerdo, un proyecto común en la ejecución de la conducta descuidada o peligrosa; b) casos de coautoría con imprudencia 
accesoria o sin acuerdo, que serían aquellos casos en los que, en el tipo objetivo, existe una co-determinación del hecho y es posible imputarle objetivamente el resultado a la conducta de cada uno de los intervinientes; pero que, en el tipo subjetivo no existió acuerdo en la ejecución de la conducta descuidada o peligrosa; y c) casos de autoría accesoria imprudente, que serían aquellos casos en los que, en el tipo objetivo, aun existiendo una co-determinación del hecho, no existe posibilidad de imputar objetivamente el resultado a la conducta de cada uno de los intervinientes; $y$, además, en el tipo subjetivo no existió acuerdo en la ejecución de la conducta descuidada o peligrosa.

9. En cuanto al contenido del acuerdo en la coautoría con imprudencia conjunta hay que señalar que no es suficiente con que cada sujeto sea consciente de que actúa con otros, o que junto a él participan otras personas, o tenga conocimiento general de la intervención de los demás. Entender que basta con que el sujeto sepa que interactúa con otros para afirmar el acuerdo sería tanto como admitir que en los supuestos de división del trabajo, la concurrencia de conductas imprudentes constituye coautoría con imprudencia, lo cual no es correcto. El acuerdo en la coautoría con imprudencia conjunta debe ser entendido en un sentido más estricto que en la coautoría con dolo conjunto. Estos sujetos deben decidir de mutuo acuerdo ("poniéndose de acuerdo") la realización de una concreta actuación en un determinado momento. En definitiva, el acuerdo debe ir referido a la concreta acción.

\section{BIBLIOGRAFÍA}

ALMELA VICH, C., "La responsabilidad penal del médico y del cirujano", en: PJ 481997, págs. 235-265.

ALPACA PÉREZ, A., Delitos tributarios y aduaneros (pról. de: DÍAZ Y GARCÍA CONLLEDO, M.), Ubi Lex, Lima, 2015.

ARAMBURO CALLE, M., "La delincuencia en la empresa: problemas de autoría y participación en delitos comunes", en: NFP 68 (2005).

ARROYO ZAPATERO, L., La protección penal de la seguridad en el trabajo (pról. de: BARBERO SANTOS, M.), Servicio Social de Higiene y Seguridad del Trabajo, Madrid, 1981.

ARROYO ZAPATERO, L., Manual de Derecho penal del Trabajo, Praxis, Barcelona, 1988.

BERGMANN, K.-O., “Aufklärung in der arbeitsteiligen Medizin”, en: VV.AA., Risiko Aufklärung. Schmerzensgeld trotz Behandlungserfolg - Wohin führt die Rechtspechung? (RATAJCZAK, T./STEGERS, C.M., coord.), Springer, Berlin/Heidelberg/New York/Hongkong/London/Meiland/Paris/Tokio, 2001.

BOCKELMANN, P./VOLK, K., Strafrecht, AT, 4ª ed., Beck, München, 1987.

BOLEA BARDÓN, C., La cooperación necesaria: análisis dogmático y jurisprudencial, Atelier, Barcelona, 2004. 
BRINKMANN, B., Der Vertrauensgrundsatzt als eine Regel der Erfehrung. Eine Untersuchung am Beispiel des Lebensmittelstrafrechts, Duncker und Humblot, Berlin, 1996.

CADAVID QUINTERO, A., Imprudencia punible y actividad médico-quirúrgica, tesis doctoral, Universidad de Salamanca, Salamanca, 2013.

CALDERÓN CEREZO, Á., “Autoría y participación en el delito imprudente. Concurrencia de culpas", en: CDJ 1993-I.

CAlderón CEREZO, Á./CHOClÁn MONTAlvo, J.A., Derecho Penal, PG, t. I, $2^{\mathrm{a}}$ ed., Bosch, Barcelona, 2001.

CEREZO MIR, J., Curso de Derecho Penal español, PG, t. II: Teoría jurídica del delito, $6^{\mathrm{a}}$ ed., Tecnos, Madrid, 1998.

CHOCLÁN MONTALVO, J.A., “La autoría y la participación”, en: LL 1996-1, págs. 1642-1646.

CHOClÁN MONTALVO, J.A., Deber de cuidado y delito imprudente, Bosch, Barcelona, 1998.

COBO DEL ROSAL, M. (dir.), Comentarios al Código penal, t. I, Edersa, Madrid, 1999.

COBO DEL ROSAL, M./VIVES ANTÓN, T.S., Derecho Penal, PG, $5^{\text {a }}$ ed., Tirant lo Blanch, Valencia, 1999.

CORCOY BIDASOlO, M., El Delito imprudente. Criterios de imputación del resultado (pról. de: MIR PUIG, Santiago), PPU, Barcelona, 1989.

DE LA MATA BARRANCO, N.J., "La participación del funcionario público en delitos comunes y especiales. Autoría y cooperación. Toma de decisiones en órganos colegiados", en: Delitos contra la Administración pública (ASÚA BATARRITA, A., ed.), Herri-Arduralaritzaren Euskal Erakundea, Bilbao, 1997.

DE VICENTE REMESAL, J./DÍAZ Y GARCÍA CONLLEDO, M., "Autoría o participación en determinados supuestos de 'vigilancia' (Comentarios a la STS de 21 de febrero de 2989) (Pte. BACIGALUPO ZAPATER)" (comentario tercero), en: PJ 27 (1992).

DEL CASTILLO CODES, E., La imprudencia: autoría y participación, Dykinson, Madrid, 2007.

DÍAZ Y GARCÍA CONLLEDO, M., "Inducción o autoría mediata en malversación impropia", en: $L L$ 1986-4.

DÍAZ Y GARCÍA CONLLEDO, M., La autoría en Derecho Penal (pról. de: LUZÓN PEÑA, Diego-Manuel), PPU, Barcelona, 1991. 
DÍAZ Y GARCÍA CONLLEDO, M., "Dominio funcional, determinación positiva y objetiva del hecho y coautoría", en: LH-Roxin (Coimbra), 1995.

DÍAZ Y GARCÍA CONLLEDO, M., “Autoría mediata, coautoría y autoría accesoria”, en: $E J B$ I, 1995.

DÍAZ Y GARCÍA CONLLEDO, M., “Autoría y participación”, en: LL 1996-2.

DÍAZ Y GARCÍA CONLLEDO, M., "Los elementos normativos del tipo penal y la teoría del error”, en: EM-Casabó I, 1997.

DÍAZ Y GARCÍA CONLLEDO, M., "El error de prohibición: pasado, presente y futuro", en: LH-Torío, 1999.

DÍAZ Y GARCÍA CONLLEDO, M., “¿Error de tipo o error de hecho?”, en: EM-Valle, 2001.

DÍAZ Y GARCÍA CONLLEDO, M., “Autoría”, en: EPB, 2002.

DÍAZ Y GARCÍA CONLLEDO, M., “Autoría mediata, coautoría y autoría accesoria”, en: $E P B, 2002$.

DÍAZ Y GARCÍA CONLLEDO, M., "La autoría en Derecho penal. Caracterización general y especial atención al Código Penal colombiano”, en: DPCrim 76 (2004).

DÍAZ Y GARCÍA CONLLEDO, M., El error sobre elementos normativos del tipo penal, La Ley, Madrid, 2008.

DÍAZ Y GARCÍA CONLLEDO, M., “Autoría y participación”, en: REJ 10 (2008).

DÍAZ Y GARCÍA CONLLEDO, M., "Der Einfluss der Roxinschen Täterschaftstheorie (insbesondere betreffend die Mittäterschaft) auf die spanische Rechtslehre und Rechtsprechung: Kritische Betrachtungen”, en: GA 2011.

DÍAZ Y GARCÍA CONLLEDO, M., "La influencia de la teoría de la autoría (en especial, de la coautoría) de Roxin en la doctrina y la jurisprudencia españolas: consideraciones críticas", en: NFP 76 (2011).

DÍAZ Y GARCÍA CONLLEDO, M., "Algunas cuestiones en relación con el delito de administración desleal societaria en España, es especial autoría y omisión”, en: NFP 83 (2014).

DÍAZ Y GARCÍA CONLLEDO, M., "Strafrechtliche Verantwortlichkeit juristischer Personen? Einige Thesen", en: GA 2016.

DÍAZ Y GARCÍA CONLLEDO, M., “¿Responsabilidad penal de las personas jurídicas? Algunas tesis", en: Libertas 2016-5.

DÍAZ Y GARCÍA CONLLEDO, M., Lectio Doctoralis: Claus Roxin y la llamada autoría mediata por utilización de aparatos organizados de poder (Laudatio dissertatio 
de PALOMINO MANCHEGO, J.F.), Serie Doctorado Honoris Causa, Universidad del Inca Garcilaso de la Vega/Universidad de León, Lima/León, 2016.

DÍAZ Y GARCÍA CONLLEDO, M., "Das Handeln im Rahmen eines organisatorischen Machtapparates: Täterschaft oder Teilnahme?”, en GA 2017.

DÍAZ Y GARCÍA CONLLEDO, M., “Actuación en el marco de un aparato organizado de poder: ¿autoría o participación?”, en: LH-Mir, 2017.

DÍAZ Y GARCÍA CONLLEDO, M., "Claus Roxin y la llamada autoría mediata por utilización de aparatos organizados de poder (Lectio doctoralis)", en: RAP 32 (2017).

DÍAZ Y GARCÍA CONLLEDO, M., "Un diálogo crítico con Claus Roxin y su teoría de la autoría", en: CPC 2017.

DÍAZ Y GARCÍA CONLLEDO, M., "Claus Roxin y la teoría de la autoría. Algunas discrepancias”, en: LH-Roxin (Lima), 2018.

DÍAZ Y GARCÍA CONLLEDO, M., “Algunos problemas que plantea la criminalidad organizada en la teoría general del delito, en especial en materia de autoría y participación", en: VV.AA., Globalización y lucha contra las nuevas formas de criminalidad transnacional (Galán Muñoz, Alfonso, Mendoza Calderón, Silvia, dirs.), Tirant lo Blanch, Valencia, 2018.

DURÁN SECO, I., La coautoría en Derecho Penal, aspectos esenciales, Secretariado de publicaciones y medios audiovisuales de la Universidad de León, León, 2003.

ESCOBAR VÉLEZ, S., La responsabilidad penal por productos defectuosos, Tirant lo Blanch, Valencia, 2012.

FEIJOO SÁNCHEZ, B., "El principio de confianza como criterio normativo de imputación en el Derecho penal: fundamento y consecuencias dogmáticas", en: $R D P C r$ $1-2000$.

FEIJOO SÁNCHEZ, B., Resultado lesivo e imprudencia: estudio sobre los límites de la responsabilidad penal por imprudencia y el criterio del "fin de protección de la norma de cuidado”, (pról. de: RODRÍGUEZ MOURULLO, G.), Bosch, Barcelona, 2001.

FRANCÉS LECUMBERRI, P., El desvalor penal de la contabilidad creativa y otras problemáticas a la luz del bien jurídico protegido en el art. 290 CP (pról. de: DÍAZ Y GARCÍA CONLLEDO, M.), Tirant lo Blanch, Valencia, 2017.

GARCÍA ÁLVAREZ, P., La puesta en peligro de la vida y/o integridad física asumida voluntariamente por su titular, Tirant lo Blanch, Valencia, 1999.

GARCÍA DEL BLANCO, M ${ }^{\mathrm{a}}$.V., La coautoría en Derecho penal (pról. de: CUERDA RIEZU, A.), Tirant lo Blanch, Valencia, 2006.

GARCÍA MOSQUERA, M., La estafa de seguro (pról. de: DE VICENTE REMESAL, J.), La Ley, Madrid, 2006. 
GIMBERNAT ORDEIG, E., Autor y cómplice en Derecho penal (pról. de: QUINTANO RIPOLLÉS, A.), Universidad de Madrid-Facultad de Derecho-Sección de Publicaciones e Intercambio, Madrid, 1966. Hay dos reimpresiones, B de F, Montevideo/Buenos Aires, 2006, 2012.

GÓMEZ MARTÍN, V., Los delitos especiales (pról. de: MIR PUIG, Santiago), Edisofer/B de F, Madrid/Montevideo, 2006.

GÓMEZ RIVERO, Mª del C., La inducción a cometer el delito (pról. de: MUÑOZ CONDE, Francisco), Tirant lo Blanch, Valencia, 1995.

GÓMEZ RIVERO, $\mathrm{M}^{\mathrm{a}}$ del C., La responsabilidad penal del médico, $2^{\mathrm{a}}$ ed., Tirant lo Blanch, Valencia, 2008.

GÓMEZ TOMILLO, M., Libertad de información y teoría de la codelincuencia. La autoría y la participación en los delitos cometidos a través de los medios de comunicación de masas, Comares, Granada, 1998.

GONZÁLEZ RUS, J.J., “Autoría única inmediata, autoría mediata y coautoría”, en: CDJ 1994-XXXIX, págs. 57-133.

GÓRRIZ ROYO, E., El concepto de autor en Derecho penal, Tirant lo Blanch, Valencia, 2002.

GUTIÉRREZ RODRÍGUEZ, M., La responsabilidad penal del coautor (pról. de: DÍAZ PITA, Ma del M.), Tirant lo Blanch, Valencia, 2001.

HAVA GARCÍA, E., La imprudencia médica, Tirant lo Blanch, Valencia, 2001.

HAVA GARCÍA, E., La imprudencia inconsciente, Comares, Granada, 2002.

HERNÁNDEZ PLASENCIA, J.U., La autoría mediata en Derecho penal (pról. de: ROMEO CASABONA, C.M ${ }^{\mathrm{a}}$.), Comares, Granada, 1996.

HERNÁNDEZ PLASENCIA, J.U., "Imputación objetiva versus dominio del hecho", en: LH-Cerezo, 2002.

JORGE BARREIRO, Ag., "Aspectos básicos de la imprudencia punible en la actividad médico-quirúrgica", EPCr XIV 1989-90.

JORGE BARREIRO, Ag., La imprudencia punible en la actividad médico-quirúrgica, Tecnos, Madrid, 1990.

JORGE BARREIRO, Ag., "Nuevos aspectos de la imprudencia jurídico-penal en la actividad médica: la culpa en el equipo médico-quirúrgico", en: MARTÍNEZ MARTÍN (coord.): Responsabilidad del personal sanitario (actas del seminario conjunto sobre la responsabilidad del personal sanitario celebrado en Madrid los días 14, 15 y 16 de noviembre de 1994), Consejo General del Poder Judicial, Madrid, 1995. 
JORGE BARREIRO, A1., “La imprudencia profesional”, en: CDJ 1993-I.

LÓPEZ BARJA DE QUIROGA, J., Autoría y participación, Akal, Madrid, 1996.

LÓPEZ BARJA DE QUIROGA, J., “El delito imprudente en el Código Penal de 1995”, en: PJ 40-1995.

LÓPEZ BARJA DE QUIROGA, J., Derecho penal. PG. II. Introducción a la teoría jurídica del delito; IV. Las consecuencias jurídicas del delito. El Derecho penal de ejecución, Marcial Pons, Madrid, 2002.

LÓPEZ PEREGRÍN, Ma .C., La complicidad en el delito, Tirant lo Blanch, Valencia, 1997.

LUZÓN PEÑA, D.-M., Aspectos esenciales de la legítima defensa (pról. de: GIMBERNAT ORDEIG, E.), Bosch, Barcelona, 1978. Hay 2. ${ }^{\mathrm{a}}$ ed., B de F, Montevideo/Buenos Aires, 2002.

LUZÓN PEÑA, D.-M., “Autoría e imputación objetiva en el delito imprudente: valoración de las aportaciones causales (Comentario a la STS de 27 de enero de 1984)", en: RDCir 1984.

LUZÓN PEÑA, D.-M., “Alcance y función del Derecho penal”, en: ADPCP 1989. Publicado también en: Estudios Penales, PPU, Barcelona, 1991).

LUZÓN PEÑA, D.-M., Derecho Penal de la Circulación. Estudios de la jurisprudencia del Tribunal Supremo, $2^{\mathrm{a}}$ ed., PPU, Barcelona, 1990.

LUZÓN PEÑA, D.-M., "El error sobre las causas de justificación: algunas precisiones (Comentario a la STS 10-5-1989)", en: Estudios Penales, PPU, Barcelona, 1991. Publicado también en: LL 1989-3.

LUZÓN PEÑA, D.-M., "Concurrencia aparente o real de error sobre presupuestos o sobre límites de una causa de justificación (Error sobre la ilegalidad de una detención intimidatoria de autoridad por funcionario)", en: Estudios Penales, PPU, Barcelona, 1991. Publicado también en: PJ 19 (1990); y en: LL 1991-1.

LUZÓN PEÑA, D.-M., "La relación del merecimiento y de la necesidad de pena con la estructura del delito", en: ADPCP 1993. Publicado también en: LH-Roxin (Coimbra), 1995.

LUZÓN PEÑA, D.-M., “Error sobre causas de justificación”, en: EJB II, 1995.

LUZÓN PEÑA, D.-M., “Tipo (penal)”, en: EJB IV, 1995.

LUZÓN PEÑA, D.-M., Curso de Derecho Penal, PG, I, $1^{\mathrm{a}}$ ed., Universitas, Madrid, 1996.

LUZÓN PEÑA, D.-M., “Error sobre causas de justificación”, en: EPB, 2002. 
LUZÓN PEÑA, D.-M., “Tipo (penal)”, en: EPB, 2002.

LUZÓN PEÑA, D.-M., Lecciones de Derecho Penal, PG, $3^{\mathrm{a}}$ ed., Tirant lo Blanch, Valencia, 2016.

LUZÓN PEÑA, D.-M./DÍAZ Y GARCÍA CONLLEDO, M., "Determinación objetiva y positiva del hecho y realización típica como criterios de autoría", en: AFDUA 8 (19981999).

LUZÓN PEÑA, D.-M./DÍAZ Y GARCÍA CONLLEDO, M., "Objektive positive Tatbestimmung und Tatbestandsverwirklichung als Täterschaftsmerkmale", en: FSRoxin, 2001.

LUZÓN PEÑA, D.-M./DÍAZ Y GARCÍA CONLLEDO, M., "Determinación objetiva y positiva del hecho y realización típica como criterios de autoría", en: RDCP 2003-2.

MARAVER GÓMEZ, M., El principio de confianza en Derecho penal. Un estudio sobre la aplicación del principio de autorresponsabilidad en la teoría de la imputación objetiva (pról. de: JORGE BARREIRO, Ag.), Civitas, Pamplona, 2009.

MIR PUIG, S., Derecho Penal, PG, 10ª ed., Reppertor, Barcelona, 2016.

MUÑoZ CONDE, F./GARCÍA ARÁN, M., Derecho Penal, $P G$, $9^{\mathrm{a}}$ ed., Tirant lo Blanch, Valencia, 2015.

OLAIZOLA NOGALES, I., El delito de cohecho (pról. de: DÍAZ Y GARCÍA CONLLEDO, M.), Tirant lo Blanch, Valencia, 1999.

OLAIZOLA NOGALES, I., El error de prohibición. Especial atención a los criterios para su apreciación y para la determinación de su vencibilidad e invencibilidad (pról. de: DÍAZ Y GARCÍA CONLLEDO, M.), La Ley, Madrid, 2007.

PAREDES CASTAÑÓN, J.M./RODRÍGUEZ MONTAÑÉS, T., El caso de la colza: responsabilidad penal por productos adulterados o defectuosos (pról. de: LUZÓN PEÑA, D.-M.), Tirant lo Blanch, Valencia, 1995.

PEÑARANDA RAMOS, E., La participación en el delito y el principio de accesoriedad (pról. de: RODRÍGUEZ MOURULLO, G.), Tecnos, Madrid, 1990.

PÉREZ ALONSO, E.J., La coautoría y la complicidad (necesaria) en Derecho penal (pról. de: ZUGALDÍA ESPINAR, J.M.), Comares, Peligros (Granada), 1998.

PÉREZ MANZANO, M., Autoría y participación imprudente en el Código Penal de 1995, Civitas, Madrid, 1999.

PÉREZ-SAUQUILLO MUÑOZ, C., "Reflexiones y críticas sobre el pensamiento de la acumulación", en: LLP 2017-128. 
RODRÍGUEZ MESA, Mª.J., "Los delitos de omisión impropia como delitos especiales y de dominio positivo del hecho. Repercusiones en materia de autoría y participación”, en: REDUR 11/2013.

RODRÍGUEZ MONTAÑÉS, T., “Imprudencia”, en: EPB, 2002.

RODRÍGUEZ VÁZQUEZ, V., Responsabilidad penal en el ejercicio de actividades médico-sanitarias (pról. de: DE VICENTE REMESAL, J.), Marcial Pons, Madrid, 2012.

ROMEO CASABONA, C.Ma ., El médico y el derecho penal I: la actividad curativa (licitud y responsabilidad penal) (pról. de: CEREZO MIR, J.), Bosch, Barcelona, 1981.

ROMEO CASABONA, C.Mª, El médico ante el Derecho (pról. HORNO LIRIA), Ministerio de Sanidad y Consumo, Madrid, 1985.

ROSO CAÑADILLAS, R., Autoría y participación imprudente (pról. de: LUZÓN PEÑA, D.-M.), Comares, Granada, 2002.

ROXIN, C., Derecho Penal, PG: Fundamentos. La estructura de la teoría del delito (trad. de la $2^{\mathrm{a}}$ ed. alemana: LUZÓN PEÑA, D.-M./DÍAZ Y GARCÍA CONLLEDO, M./DE VICENTE REMESAL, J.), Civitas, Madrid, 1997.

ROXIN, C., Strafrecht, AT: Grundlagen, der Aufbau de Verbrechenslehre, Bd. 1, $4^{\mathrm{a}}$ ed., Beck, München, 2006.

ROXIN, C., Autoría y dominio del hecho en Derecho penal (trad. de la $7^{\mathrm{a}}$ ed. alemana: CUELLO CONTRERAS, J./SERRANO GONZÁLEZ DE MURILLO, J.L.), Marcial Pons, Madrid, 2000. Hay una nueva ed. del 2016.

SAINZ-CANTERO CAPARRÓS, J.E., La “codelincuencia” en los delitos imprudentes en el Código penal de 1995, Marcial Pons, Madrid, 2001.

SÁNCHEZ-CARO, J./ABELLÁN, F.: Derechos y deberes de los pacientes. Ley 41/2002 de 14 de noviembre: consentimiento informado, historia clínica, intimidad e instrucciones previas (pról. de: FARIÑA GONZÁLEZ, J.), Comares, Granada, 2003.

SÁNCHEZ LÁZARO, F.G., Intervención delictiva e imprudencia (pról. de: ROMEO CASABONA, C.M.), Comares, Granada, 2004.

SÁNCHEZ LÁZARO, F.G., "El ocaso de la resolución conjunta. Recensión a Victoria García del Blanco, La coautoría en Derecho penal, Tirant lo Blanch, Valencia, 2006, 734 p.", InDret 2/2007.

SCHÖNKE, A./SCHRÖDER, H., en: VV.AA, StGB, Kommentar, (a cargo de LENCKNER， T./CRAMER， P./ESER， A./STREE， W./EISELE， J./HEINE, G./PERRON, W./STEERNBERG-LIEBEN, D./SCHITTENHELM), $28^{\mathrm{a}}$ ed., Beck, München, 2010. 
SOTO NIETO, F., "Responsabilidad penal derivada de la actividad médica", en: VV.AA, Derecho médico. Tratado de Derecho sanitario (MARTÍNEZ CALCERRADA, L./DE LORENZO Y MONTERO, R., dirs.), t. I, II, III, Colex, Madrid, 2001.

SOTO NIETO, F., “Coautoría en los delitos de imprudencia médica”, en: LL 2002-7.

STRATENWERTH, G., "Arbeitsteilung und ärztliche Sorgfaltspflicht", en: $F S-E b$. Schmidt, 1961.

STRATENWERTH, G., Derecho Penal, PG, I: El hecho punible (trad. de: ROMERO, Gladis), Madrid, Edersa, 1982.

STRATENWERTH, G., Strafrecht, AT, I: Die Straftat, 4ª ed., München, Heymanns, 2000.

SILVA SÁNCHEZ, J.-M., "Aspectos de la responsabilidad penal por imprudencia del médico anestesista. La perspectiva del Tribunal Supremo", en: DS 2-1994.

SUÁREZ SÁNCHEZ, A., Autoría, $3^{\text {a }}$ ed., Universidad Externado de Colombia, Bogotá, 2007.

TORRES CADAVID, N., "La responsabilidad penal del asesor fiscal en el delito de defraudación tributaria del art. 305 CP español. La aplicación de la cláusula del actuar en lugar de otro", NFP 90 (2018).

TORRES CADAVID, N., La responsabilidad penal del asesor fiscal. Problemas de autoría y participación en el delito de defraudación tributaria (pról. de: DÍAZ Y GARCÍA CONLLEDO, M.), Tirant lo Blanch, Valencia, 2019.

TRAPERO BARREALES, María A.: El error en las causas de justificación (pról. de: LUZÓN PEÑA, Diego-Manuel), Tirant lo Blanch, Valencia, 2004.

TRILLO NAVARRO, J.P., "Imprudencia en la cirugía estética. Coautoría y continuidad", en: LLP 2007-43.

VALLEJO JIMÉNEZ, G.A., Responsabilidad penal sanitaria: problemas especificos en torno a la imprudencia médica, tesis doctoral, Universidad de León, León, 2012.

VILLACAMPA ESTIARTE, C., Responsabilidad penal del personal sanitario. Atribución de responsabilidad penal en tratamientos médicos efectuados por diversos profesionales sanitarios, Thomson-Aranzadi, Cizur Menor, 2003.

WELZEL, H., Das Deutsche Strafrecht. Eine systematische Darstellung, $11^{\mathrm{a}}$ ed., Walter de Gruyter, Berlin, 1969.

WELZEL, H., Derecho Penal alemán, PG (trad. de: BUSTOS RAMÍREZ, J./YÁÑEZ PÉREZ, S.), $2^{\mathrm{a}}$ ed. (en español), Editorial Jurídica de Chile, Santiago de Chile, 1976. 
ZAFFARONI, R.E./AlAGIA, A./SLOKAR, A.W., Derecho penal, PG, $3^{\text {a }}$ ed., Ediar, Buenos Aires, 2005.

ZUGALDÍA ESPINAR, J.M., “Algunas observaciones sobre los principios que inspiran la jurisprudencia española en materia de delitos de tráfico", en: RDCir 1981. 